Florida International University FIU Digital Commons

6-18-2002

\title{
The effects of sexual harassment severity and organizational policy and response on juror damage awards
}

Stacie Ann Cass

Florida International University

DOI: $10.25148 /$ etd.FI14060100

Follow this and additional works at: https://digitalcommons.fiu.edu/etd

Part of the Psychology Commons

\section{Recommended Citation}

Cass, Stacie Ann, "The effects of sexual harassment severity and organizational policy and response on juror damage awards" (2002). FIU Electronic Theses and Dissertations. 2068.

https://digitalcommons.fiu.edu/etd/2068 
Miami, Florida

THE EFFECTS OF SEXUAL HARASSMENT SEVERITY AND ORGANIZATIONAL POLICY AND RESPONSE ON JUROR DAMAGE AWARDS

\author{
A thesis submitted in partial fulfillment of the \\ requirements for the degree of \\ MASTER OF SCIENCE \\ in \\ PSYCHOLOGY \\ by \\ Stacie Ann Cass
}


To: Dean Arthur W. Herriott

College of Arts and Sciences

This thesis, written by Stacie Ann Cass, and entitled The Effects of Sexual Harassment Severity and Organizational Policy and Response on Juror Damage Awards, having been approved in respect to style and intellectual content, is referred to you for judgment.

We have read this thesis and recommend that it be approved.

Christian A. Meissner

Rebecca M. Salokar

Margaret Bull Kovera, Major Professor

Date of Defense: June 18, 2002

The thesis of Stacie Ann Cass is approved.

Dean Arthur W. Herriott

College of Arts and Sciences

Dean Douglas Wartzok

University Graduate School

Florida International University, 2002 


\section{DEDICATION}

I dedicate this thesis to my new husband, Matthew Harasty, and my family. Matthew, without your enduring support and patience, I would not have had the strength to bring this project to fruition. My dear family, your loving emails and phone calls have helped me along my journey to the completion of this thesis. I would like to offer a special thank you to my mother for altering her plans to ensure that I was healthy enough to defend this thesis. I also wish to thank Bibiana Arbelaez, for without her hard work during data collection and constant encouragement I may still be working on this project. I would also like to thank two of my undergraduate professors, Dr. Elizabeth Bennett and Dr. Nicholas Cavoti, for encouraging me to apply to graduate school. Finally, I would like to thank John Marshall. Thank you. 


\section{ACKNOWLEDGMENTS}

I wish to thank Dr. Margaret Bull Kovera, my chairperson, for her commitment to my thesis. This project would not be what it is without your dedication, time, and guidance. I cannot thank you enough for your constant encouragement and patience. I also want to thank Dr. Christian Meissner and Dr. Rebecca M. Salokar, whose insightful and creative suggestions have helped to improve my thesis. Thank you also to the APLS grants-in-aid for providing me with a grant of $\$ 500$ to conduct this study. Finally, I would like to thank Dolly Gibson and her staff, Patricia Todaro and Steven Framer, at the Broward County Courthouse in Ft. Lauderdale, Florida. I would still be collecting data without your assistance. Thank you all. 


\title{
ABSTRACT OF THE THESIS
}

THE EFFECTS OF SEXUAL HARASSMENT SEVERITY AND ORGANIZATIONAL

\section{POLICY AND RESPONSE ON JUROR DAMAGE AWARDS}

by

\author{
Stacie Ann Cass
}

Florida International University, 2002

Miami, Florida

Professor Margaret Bull Kovera, Major Professor

Community members who reported for jury duty $(\underline{\mathrm{N}}=123)$ read a brief summary of a sexual harassment trial, in which harassment severity and the organization's sexual harassment policy were manipulated. Jurors were more likely to agree that they should compensate the plaintiff for her pain and suffering, the organization should be punished, and the plaintiff had suffered when they read the more severe harassment scenario. When the organization had and enforced an effective sexual harassment policy, jurors believed that the plaintiff had suffered little and the organization should not be punished. Thus, severity of harassment influenced jurors' judgments about compensation, and organizational policy influenced jurors' judgments about punishment, both legally appropriate considerations. These results have implications for both organizations, who could create or modify sexual harassment policy to limit damage awards, and trial lawyers, who could tailor trial arguments to maximize or minimize awards. 
I. INTRODUCTION AND LITERATURE REVIEW

Compensatory Damages.................................................................... 2

Factors Affecting Jurors' Compensatory Damage Awards..................... 2

The Damages Caused by Sexual Harassment .......................................... 4

Punitive Damages ................................................................................ 7

Factors Affecting Jurors' Punitive Damage Awards................................ 8

Fusion of Compensatory and Punitive Damages ........................................ 9

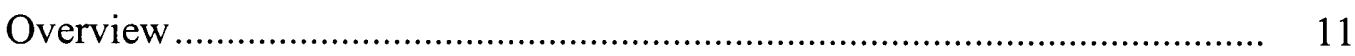

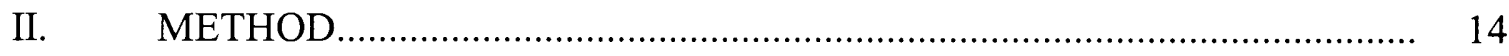

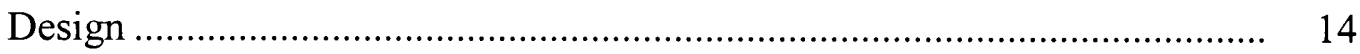

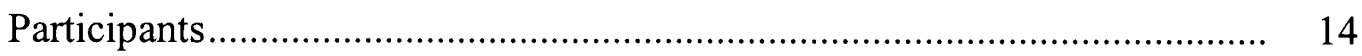

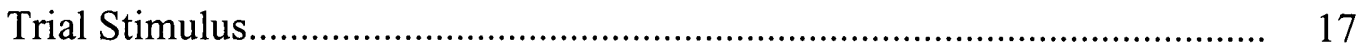

Sexual Harassment Severity ............................................................. 18

Organization's Policy and Response ..................................................... 19

Dependent Measures ............................................................................. 20

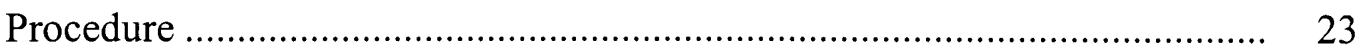

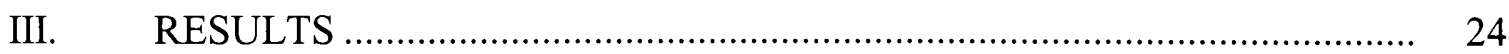

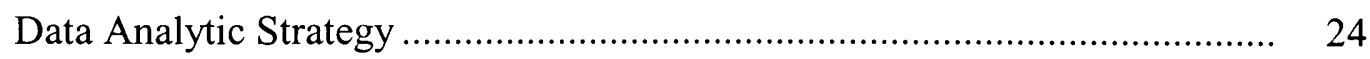

Manipulation Checks ....................................................................... 24 
Effects of Harassment Severity ……...................................................... 25

Effects of Organizational Sexual Harassment Policy and Response ............. 27

Path Models of Juror Decision Making in Sexual Harassment Cases ........... 29

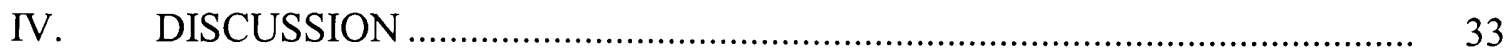

The Effects of Harassment Severity and Implications .................................. 34

The Effects of the Organizational Policy and Response and Implications ..... 38

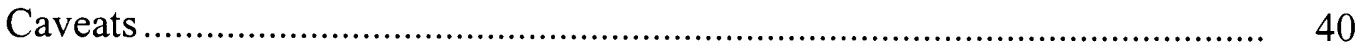

Conclusions ............................................................................. 41

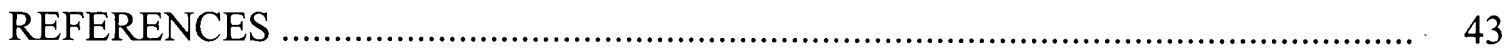

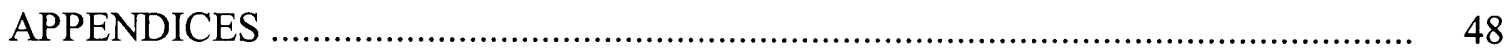


Chapter One: Introduction and Literature Review

Experts estimate that approximately $35-50 \%$ of all working women have experienced sexual harassment (Gutek \& Done, 2001). The most prevalent forms of sexual harassment include unwanted physical contact, sexually explicit language, sexual propositions linked to employment, and requests for dates (Cochran, Frazier, \& Olson, 1997; Terpstra \& Cook, 1985). Of these, the less severe types of sexual harassment (e.g. unwanted sexual teasing, jokes, remarks, and questions followed by unwanted sexual looks or gestures) are the most frequent (Cochran et al., 1997; O'Connell \& Korabik, 2000). Issues of sexual harassment in the workplace can be extremely contentious and the laws designed to define what conduct constitutes sexual harassment are unnecessarily vague (Gutek, O'Connor, Melançon, Stockdale, Geer, \& Done, 1999). A juror's task of assigning liability in sexual harassment cases is further complicated by the frequent lack of physical evidence of the alleged misconduct. In addition to determining liability, Title VII of the Civil Rights Act of 1991 requires jurors to determine damages for pain and suffering as well as mental anguish for victims of sexual harassment who seek such compensation. Before Title VII, plaintiffs could only be compensated for out-of-pocket medical expenses and lost economic opportunities (e.g. back pay or lost promotions, Andrew \& Andrew, 1997). Plaintiffs had to file tort cases to recover damages for emotional pain and suffering (Goodman-Delahunty \& Foote, 1995).

To date, researchers have examined how jurors make liability decisions in sexual harassment cases (Gutek et al., 1999; Kovera, McAuliff, \& Hebert, 1999; Wiener, Hurt, Russell, Mannen, \& Gasper, 1997; Wiener, Watts, Goldkamp, \& Gasper, 1995) but have ignored what happens after jurors find a defendant liable (Kovera \& Cass, 2002). 
Numerous questions about how jurors confer damages remain. Do jurors demonstrate common understanding of the consequences of sexual harassment through the damage awards they return? Does harassment severity influence compensatory damage awards, as the law suggests it should? Do jurors consider only relevant information about the organization's sexual harassment policy and response when conferring punitive damage awards?

\section{Compensatory Damages}

The law stipulates what factors a juror may consider when awarding both compensatory and punitive damages. Compensatory damages are intended to return the plaintiff to the state of life he or she experienced before the injury (Cather, Greene, \& Durham, 1996; Goodman-Delahunty \& Foote, 1995; Greene \& Loftus, 1998). This type of damages may be influenced by both economic losses (i.e., past and future loss of income as well as medical expenses) and non-economic losses, including pain and suffering, emotional distress, and impairment of the plaintiff's quality of life (e.g., limitations on lifestyle options and enjoyment of life; Cather et al., 1996; Greene \& Loftus, 1998). Awards for future lost income and medical expenses are subject to caps based on the number of employees that work for the defendant's employer, although jurors are not made aware of these caps as the limit is imposed by the trial judge following the jury's decision (Goodman-Delahunty \& Foote, 1995).

Factors Affecting Jurors' Compensatory Damage Awards. The majority of studies have shown that jurors can and do typically award damages appropriately (Cather et al., 1996; Greene \& Loftus, 1998; Greene, Woody, \& Winter, 2000; Wissler, Evans, Hart, Morry, \& Saks, 1997). Research into how jurors award compensatory damages 
indicates that jurors consider pain and suffering (Mott, Hans, \& Simpson, 2000), injury severity (Mott et al., 2000; Robbennolt \& Studebaker, 1999; Wissler et al., 1997), and duration of injury (Wissler et al., 1997) when awarding compensatory damages to a plaintiff in personal injury, automobile negligence, medical malpractice, and insurance bad faith cases. The more severe jurors perceive the injury to be, the higher the pain and suffering award they return is (Robbennolt \& Studebaker, 1999). Jurors are most influenced by plaintiff's mental suffering when formulating their awards, followed by the severity of the disability and the severity of the pain experienced (Wissler et al., 1997). Jurors, appropriately, do not consider information about the defendant's behavior or wealth when assessing compensatory damage awards (Robbennolt \& Studebaker, 1999). The amount of responsibility assessed to the plaintiff does not affect compensatory damage awards (Vidmar, Lee, Cohen, \& Stewart, 1994). In wrongful death cases, jurors inappropriately consider, however, the sex of the deceased when conferring compensatory damage awards, such that male decedents received higher awards than female decedents (Goodman, Loftus, Miller, \& Greene, 1991).

Thus, research demonstrates that jurors do not make compensatory awards in an indiscriminate manner. Jurors report that they compute a fair award figure rather than arbitrarily picking a number based on their emotions in the case (Zickafoose \& Bornstein, 1999). Research also indicates that the caps on damage awards proposed by critics would hinder rather than assist a juror in determining awards. Saks, Hollinger, Wissler, Evans, and Hart (1997) demonstrate that caps increased variability in cases of low and medium injury severity, while artificially depressing awards in cases of extreme injury severity. 
The Damages Caused by Sexual Harassment. The concept of pain and suffering is a critical component of compensatory damages. However, the pain and suffering experienced by victims of sexual harassment may differ from the pain and suffering experienced by victims of personal injury, automobile negligence, medical malpractice, and insurance bad faith. Sexual harassment is unlikely to result in physical injuries or death typical of personal injury, automobile negligence, medical malpractice, or insurance bad faith. It is possible that because jurors cannot see sexual harassment damages as they can other types of injuries, they may be inclined to doubt both whether the plaintiff has experienced damages as the result of sexual harassment, as well as doubt the extent to which the plaintiff has suffered. Thus, it is important to review the research on the emotional sequelae resulting from sexual harassment. Between $21-82 \%$ of sexually harassed women report decreased physical and emotional health (Koss, 1990). The most commonly reported symptoms include anxiety, insomnia, stress, depression, lower self-esteem, nervous breakdowns, excessive fatigue (Crull, 1982; GoodmanDelahunty \& Foote, 1995; Gutek, 1985; Koss, 1990; Webb, 1994), loss of appetite, binge eating, extreme weight loss, prolonged nausea, headaches, frequent bouts of crying without provocation (Crull, 1982; Gutek, 1985; Koss, 1990; Webb, 1994), marital strain, and humiliation (Goodman-Delahunty \& Foote, 1995). Victims of sexual harassment are frequently diagnosed with and treated for acute anxiety disorder, disorder of extreme stress not otherwise specified, generalized anxiety disorder, panic disorders (possibly with agoraphobia), somatoform disorders, depression, and/or post-traumatic stress disorder (Goodman-Delahunty \& Foote, 1995). 
Victims also frequently report job-related consequences of sexual harassment including increased absenteeism, tardiness, and thoughts of leaving their jobs (Fitzgerald, Drasgow, Hulin, Gelfand, \& Magley, 1997; O’Connell \& Korabik, 2000). Some victims claim that the sexual harassment they experienced only decreased their satisfaction with coworkers (Fitzgerald, Hulin, Drasgow, 1994; Goldenhar, Swanson, Hurrell, Ruder, \& Deddens, 1998; Yoder \& Aniakudo, 1995), but others report an overall reduction in job satisfaction (O'Connell \& Korabik, 2000). Numerous legal cases demonstrate the effects of sexual harassment on its victim (Cross v. State of Alabama, 1995; Ellison v. Brady, 1991; Hall v. Gus Construction Co., 1988; Harris v. Forklift Systems, Inc., 1993; Meritor Savings Bank v. Vinson, 1986; Robinson v. Jacksonville Shipyards, 1991). These cases reveal that victims report the effects of sexual harassment manifesting in the form of reduced job involvement, poor job performance, decreased job satisfaction, increased absenteeism, increased thoughts of leaving the job, deterioration of interpersonal relationships, and increased job stress.

The frequency, duration, and subjective ratings of the sexual harassment affect a victim's ratings of the event's severity (Schneider, Swan, \& Fitzgerald, 1997). Sixty-four percent of women reported that the sexual harassment lasted between one week and six months and $74 \%$ stated that the sexual harassment occurred frequently (i.e., once per month to almost daily, Schneider et al., 1997). The incidences of sexual harassment, which were frequently sexist put-downs and other insulting sexual comments, were rated as offensive or extremely offensive by $66 \%$ of the women (Schneider et al., 1997). Eighty-three percent reported being forced to continue working with her harasser 
(Schneider et al., 1997). Thus, sexual harassment did not have to be particularly flagrant to be perceived as such by its victims.

Frequent incidents of low level sexual harassment (e.g., sexist insults and offensive sexual comments) are just as likely to result in negative consequences for the victim as more severe harassment. Both women in academia and the private sector reported negative job-related and psychological outcomes as a result of the harassment (Schneider et al., 1997). Additionally, women need not label themselves as victims of sexual harassment to experience negative effects from the harassment (Schneider et al., 1997). The frequency and type of hostile work environment, however, increased the severity of the emotional sequelae experienced by sexual harassment victims (Schneider et al., 1997). Thus, it is important to determine whether the effects that type and frequency of harassment have upon damage awards is consistent with the effects of these factors on the psychological consequences for the women who experienced the harassment.

As mentioned previously, Schneider and her colleagues (1997) found that the frequency of the harassment affected overall ratings of the severity of the harassment. As such, it may be warranted in early stages of research to combine ratings of frequency and severity into a global measure of the pervasiveness of the harassment. Studies, using vignettes, have demonstrated that the frequency of the harassment has an effect on appropriateness ratings, such that more frequent harassment was perceived as less appropriate than was less frequent harassment (Hurt, Maver, \& Hofman, 1999). Victims of sexual harassment also report more frequent harassment as being more offensive than 
less frequent harassment (Brooks \& Perot, 1991; Langhout, Bergman, Cortina, Fitzgerald, Drasgow, \& Hunter Williams, 1999).

If the severity of the harassment increases the emotional suffering experienced by plaintiffs, then severity should appropriately affect jurors' compensatory damage awards, such that severe harassment leads to extreme pain and suffering on behalf of the plaintiff and in turn results in higher compensatory damages than mild harassment. If jurors ascribe to the idea that any harassment is severe harassment, as Schneider and her colleagues' research suggests, then jurors' compensatory damage should be constant across conditions. Jurors who believe that any harassment has severe consequences for the harassed may instead opt to use information about the severity of the harassment when determining punitive damages. More severe harassment may be perceived by jurors as being more malicious and as such result in jurors returning larger punitive damage awards than they would when the harassment is viewed as being mild.

\section{Punitive Damages}

Punitive damages are intended to punish the defendant as well as to deter the defendant and others from engaging in similar behavior in the future (Greene \& Loftus, 1998). A jury may award punitive damages only if the defendant's behavior is wanton or willful. The more reprehensible the defendant's behavior is, the higher the punitive damage awards should be (Greene \& Loftus, 1998). The jury should consider several factors when determining whether the defendant's behavior is reprehensible. If the consequences of the defendant's behavior are foreseeable or if the defendant's behavior is reckless or malicious, then the defendant's behavior should be considered more reprehensible. 
Factors Affecting Jurors' Punitive Damage Awards. Research on punitive damages has shown that jurors consider legally appropriate factors when determining awards. Jurors confer higher awards when the defendant's behavior is perceived as being extremely reprehensible as opposed to less reprehensible (Cather et al., 1996; Robbennolt \& Studebaker, 1999). The severity of the plaintiff's injuries had no affect on the amount of punitive damages assessed on the defendant (Cather et al., 1996).

Punitive damages, historically, were awarded in cases that could now be considered sexual harassment cases or cases in which politicians are charged with misuse of power (Hastie, Schkade, \& Payne, 1999). Legally, companies that provide a timely response to an employee's sexual harassment complaint should be viewed as less reprehensible than companies who do not make valid attempts to rectify instances of sexual harassment (Andrew \& Andrew, 1997; Kolstad v. ADA, 1999). Further, organizations that have proactive sexual harassment policies, thereby making a goodfaith effort to comply with Title VII, should not be held responsible for the malicious or evil actions of one or more employees (Kolstad v. ADA, 1999). As such, these organizations should not be assessed punitive damages. Research has shown that sexual harassment victims who perceive their workplace to be unresponsive to their allegations later report having endured more severe harassment than victims whose organization responded in a timely, effective manner report (Fitzgerald et al., 1997).

I predicted that jurors will use information about an organization's policy and response when conferring punitive damage awards. Whether it is legally appropriate to do so is a determination that must be made on a case-by-case basis given information about the defendant's proactive measures to prevent sexual harassment from occurring in 
the workplace. If an organization requires sexual harassment training of all employees, provides sexual harassment with effective means of filing complaints, and punishes those guilty of harassing fellow employees, then the organization legally should not be held responsible for punitive damages (Kolstad v. ADA, 1999). Jurors may use information about the organization's policy and response when judging the severity of the harassment. Consideration of such information may result in inflated compensatory damage awards as jurors use information twice.

Fusion of Compensatory and Punitive Damages.

If issues of compensatory and punitive damages were as clear cut as previously explained, researchers, lawyers, judges, and others would not continue to debate the appropriateness of damage awards. To date, researchers have primarily used cases of personal injury, automobile negligence, medical malpractice, and insurance bad faith to study jurors' awards. Even in such limited types of cases, much debate exists over jurors' ability to appropriately assess damage awards. Jurors blatantly disregard instructions from the judge to ignore attorney's specific monetary requests when formulating their awards (Hastie, et al., 1999). Eighty percent of jurors in one study claimed to have considered attorney's fees when assessing compensatory damages (Mott et al., 2000).

Also, jurors consider irrelevant and inappropriate factors while disregarding the factors that they should consider (Anderson \& MacCoun, 1999; Cather et al., 1996; Feigenson, Park, \& Salovey, 1997; Goodman et al., 1991; Greene, Johns, \& Smith, 2001; Hastie et al., 1999; Mott et al., 2000; Robbennolt \& Studebaker, 1999). Some jurors have inflated overall awards for plaintiffs whom they believe have lower incomes and greater 
financial need by inflating awards for pain and suffering (Anderson \& MacCoun, 1999; Goodman et al., 1991). When the plaintiff's injury was mild, the reprehensibility of the defendant's conduct increased compensatory damage awards but the reprehensibility of the defendant's conduct had no effect on compensatory damages when the plaintiff's injuries were severe (Greene et al., 2001). Compensatory damages were lower when jurors attributed more blame for the incident to the plaintiff than when they thought that the plaintiff was less at fault for his or her injuries (Feigenson et al., 1997). The amount of blame attributed by jurors to the plaintiff mattered when jurors perceived the plaintiff's injuries to be severe than when they believed the injuries were mild (Feigenson et al., 1997).

Research on punitive damage awards has also shown that jurors use flawed processes when determining awards. If jurors believe that the defendant is wealthy, they are likely to render higher awards than if they believe the defendant is not wealthy (e.g., Bornstein, 1994; Robbennolt \& Studebaker, 1999; c.f. Hans, 2000; MacCoun, 1996; Vidmar et al., 1994). These findings suggest that jurors use inapplicable information about injury severity and defendant conduct when awarding damages in non-sexual harassment cases. I believe that because injuries in sexual harassment cases are more ambiguous than the physical injuries described in the existing research, jurors will have an even more difficult time appropriately awarding damages in sexual harassment cases. For example, it may be easier for jurors to imagine how the loss of a limb would have detrimental effects on the quality of one's life than to imagine how depression may adversely affect a victim of sexual harassment. 
Moreover, when an organization does not respond forcefully when it receives a complaint of harassment, a juror may perceive the victim as having suffered more severe harassment and award higher compensatory damages than when an organization responds to a sexual harassment complaint in a timely and effective manner. In instances of pervasive harassment, I anticipate that jurors will not be able to separate the harasser's reprehensible behavior from the organization's response and award higher punitive damage awards, even in cases in which the organization responded to the sexual harassment in an appropriate manner.

Overview

The goal of this study was to examine jurors' common understanding of sexual harassment by examining how jurors make damage awards in sexual harassment cases. As previously mentioned, past research has used cases of personal injury, automobile negligence, medical malpractice, and insurance bad faith. Jurors may be better able to comprehend the physical injuries reported by plaintiffs in such cases as opposed to the intangible, psychological injuries that frequently occur as a result of sexual harassment. It is not clear that awarding damages in a legally appropriate manner indicates that an individual comprehends the sequelae caused by sexual harassment. As the law is currently written, a plaintiff who has experienced more severe harassment is presumed to have suffered more and as such should be entitled to higher damage awards for pain and suffering. Researchers, however, have had difficultly differentiating between victims who have been frequently and infrequently harassed and who have experienced severe or mild harassment (Schneider et al., 1997). Schneider and her colleagues (1997) only found differences in psychological and work-related outcomes between women who had 
and had not been sexually harassed. It is likely that jurors are unaware of such research and therefore assume that plaintiffs who claim having been subjected to mild harassment are only mildly damaged and as a result are entitled to lower damage awards than a victim of more severe harassment. Jurors may also have difficulty distinguishing between the behavior of the individual who perpetrated the sexually harassing acts and the organization on trial, as the individual harassers are frequently not on trial in sexual harassment cases. In cases in which an organization is the defendant, the reprehensibility of the organization's behavior, not that of the individual harasser(s), should determine the size of any punitive damage awards. Jurors should perceive companies that do not attempt to prevent punish sexual harassment or punish harassers as more reprehensible than companies that make an attempt. If an organization provides an environment in which sexual harassment is blatantly intolerable and individuals are provided with a safe and effective means of reporting sexual harassment claims, a juror may perceive this victim has having suffered less than a victim in a less supportive environment and as a result, jurors may award less in compensatory damages. This belief is consistent with research finding that sexual harassment victims who perceive that their organization is tolerant of sexual harassment suffer more severe consequences than victims who believe that their organization does not tolerate sexual harassment (Fitzgerald et al., 1997). As such, lower pain and suffering awards would be warranted in cases where the organization responded in an effective, timely manner to allegations of sexual harassment.

Jury eligible citizens read a brief trial summary based on an actual sexual harassment case (Robinson v. Jacksonville Shipyards, Inc., 1991). This summary 
manipulated the severity of the harassment experienced by the plaintiff as well as the organization's sexual harassment policy and reaction to the plaintiff's complaint. After reading the trial summary, participants completed a questionnaire designed to assess damage awards. The questionnaire also measured jurors' beliefs about the case and the trial participants. Finally, jurors provided demographic information.

I predicted that jurors would consider the severity of the harassment when awarding punitive damage awards. More severe harassment would result in higher compensatory damage awards than less severe harassment. Further, I believed that information about the defendant's sexual harassment policy and response would influence punitive damages such that organizations that are both proactive and punitive when responding to sexual harassment allegations would be assessed lower punitive damages than organizations that have no policy. If jurors award damages in a legally appropriate manner then one could argue that jurors seem to have a common understanding of the consequences of sexual harassment, at least as far as such understanding influences damage awards.

I also believed that jurors' responses to a number of trial related questions would provide insight into their common understanding of sexual harassment. Participants who read the severe summary should rate the plaintiff as having suffered more and believe more strongly that the organization was a hostile work environment than participants who read the mild summary. An organization's policy and response should influence both jurors' ratings of whether the plaintiff worked in a hostile work environment as well as whether the company deserves to be punished for its actions. 
Design

The experiment consisted of a 2 (Sexual Harassment Severity: Low vs. High) X 2 (Organization Policy: No Policy vs. Enforced Policy) factorial design. The mean age of participants was 44 years ( $S D=13$ years), with a range of 18 to 73 years. Fifty-five percent of the participants were women and $41 \%$ were men. ${ }^{1}$ Other demographics (e.g., education level, race, marital status, income level, sexual harassment experience, and jury experience) can be found in Table 1. The majority of participants in this study had at least some college education (87\%). Sixty-nine percent of the participants were white and approximately $50 \%$ were married. The mean household income for 2000 was equally distributed between less than $\$ 45,000$ to more than $\$ 75,000$. Most participants were neither victims of sexual harassment nor charged with sexual harassment. Less than half of the prospective jurors had previously served on a jury.

\section{Participants}

One hundred and twenty-eight jury eligible community members who reported for jury service at Broward County Courthouse in Ft. Lauderdale, Florida $(N=128)$ participated in this study.

\footnotetext{
${ }^{1}$ Percentages do not sum to $100 \%$ because not all participants responded to all demographic questions.
} 
Table 1

Self-reported demographic information.

Demographic

n

$\%$

Education

126

High school or less

At least some college or college degree

Some graduate school or graduate degree

Race

125

White, non-Hispanic

Black, non-Hispanic

Hispanic

Asian

Cuban

Other

Marital Status

Single

Married

Divorced

Widowed

Partnered 
Table 1 continued

Self-reported Demographic Information.

$\begin{array}{lll}\text { Demographic } & n & \%\end{array}$

Income Level

118

Less than $\$ 45,000$

$\$ 45,000$ to $\$ 75,000$

More than $\$ 75,000$

Victim of Sexual Harassment

Yes

No

Charged with Sexual Harassment

126

Yes

No 


\section{Trial Stimulus}

Jurors read a five page trial summary of a simulated hostile work environment sexual harassment case (Appendix A). This summary is based on the trial summary used by McAuliff \& Kovera (2001), which was derived from the case facts in Robinson $v$. Jacksonville Shipyards, Inc. (1991). All versions of the summary presented clear evidence of liability. The trial summary contained opening statements by the plaintiff and defense attorneys, testimony from two plaintiff and two defense witnesses, closing arguments by both attorneys, and the $11^{\text {th }}$ Circuit Court of Appeals 1999 Civil Jury Instructions for sexual harassment cases. To eliminate the possibility that participants would not assess liability in each of the four conditions and as such not confer damage awards, the summary ended by informing the participants that the defendant was liable.

The plaintiff testified on her own behalf stating that she worked among an allmale team as a mechanic at a trucking organization. The plaintiff described sexual pictures that were displayed and sexual incidents that occurred in her workplace. She also described the organization's reaction to her complaints. She stated that because of the environments sexually charged and hostile environment that she missed days of work and passed up needed overtime. During cross-examination, the plaintiff admitted that she frequently used profanity with her coworkers. The plaintiff also testified that she supplemented her lost wages and overtime by working as a part-time massage therapist.

One of the plaintiff's female coworkers, from a different department, testified that her responsibilities for the trucking organization brought her into the plaintiff's work area, the maintenance garage, approximately once per week. She testified that she had seen the pictures described by the plaintiff. On cross-examination, she testified that the 
pictures did not offend her and that the men in the garage had never made any sexual advances either in her presence or toward her.

A divisional director and the plaintiff's shift supervisor both testified for the defense. The shift supervisor acknowledged the presence of the questionable pictures but claimed that these images did not appear to bother the plaintiff until he reprimanded her for missed days and tardiness. He also stated that he did not believe that the material was sexually explicit and that the plaintiff frequently used profanity with her male coworkers. The director testified that the plaintiff had met with him to discuss the objectionable pictures. He testified that he offered to follow up on the alleged misconduct but the plaintiff was either unwilling or unable to provide him with the names of the offenders. He stated that the working environment at the trucking organization is not a hostile one and that every effort is made to be sensitive to the needs and feelings of female employees.

Varying testimony by the four witnesses conveyed the experimental manipulations to the participants. The pervasiveness of the sexual harassment as well as the organization's response varied across conditions. Participants were instructed at the end of the trial summary that jurors determined liability in a previous stage of the trial and that it is their job now to determine damage awards.

Sexual Harassment Severity. In the severe harassment condition, the alleged pictures depicted men and women engaging in sexual acts, the crude comments were directed at the plaintiff, and the male coworkers referred to the plaintiff in offensive terms, such as "whore" and "slut." The male coworkers harassed the plaintiff about her sex life. The plaintiff also testified that her male coworkers would brush up against her 
breasts and buttocks while working on the trucks. The objectionable acts occurred and the pictures appeared daily, and the plaintiff's coworkers constantly engaged in sexual conversation.

In the mild harassment condition, the pictures in question depicted scantily clad women, although no nudity or sexual acts were contained in these images. Offensive comments were made in the presence of the plaintiff rather than being directed at her, and the coworkers call women, in general, "sluts" and "whores." The male coworkers talked generally about their sex lives and encourage the plaintiff to join their conversation. The pictures were posted occasionally, and the sexual incidents, sexual conversation, and rude comments occurred weekly.

Organization's Sexual Harassment Policy and Response. The organization's sexual harassment policy and response to the plaintiff's complaint was the other manipulated variable. In the no policy condition, no sexual harassment training was required of employees as a condition of employment. The supervisors promised to remove the pictures but did not. The organization did not reprimand the perpetrator of the sexual incident and the sexual comments were not prohibited.

In the enforced policy condition, for the past five years the organization had required sexual harassment training of all employees. The shift supervisor immediately removed the questionable pictures following the plaintiff's complaint. The organization reprimanded the individual responsible for the sexual act and required him to take sensitivity training classes. The divisional director met with the mechanics to remind them to be sensitive to their female coworkers. Additionally, the organization distributed a memo reminding employees of the organization's sexual harassment policy. 


\section{Dependant Measures}

Participants were informed that they could choose to award either or both compensatory and punitive damages to the plaintiff. Specifically, participants provided dollar amounts in each of several categories of compensatory (i.e., lost wages, future lost wages, medical expenses, future medical expenses, and pain and suffering) and punitive (i.e., to punish the defendant for its behavior, to deter the defendant from engaging in such behavior in the future, and to deter other companies from engaging in similar behavior in the future) damages. Specific requests by the plaintiff's attorney for lost wages and medical expenses were included in all versions of the trial summary. Next jurors rated the extent to which they believed that the plaintiff worked in a hostile work environment, the plaintiff should be compensated for her injuries, and the organization should be punished for its conduct. Jurors also evaluated the credibility of each witness on fourteen bipolar adjective pairs: moral/immoral, respectable/not respectable, intelligent/unintelligent, good/bad, likable/not likable, qualified/not qualified, trustworthy/untrustworthy, honest/dishonest, sincere/insincere, believable/not believable, convincing/not convincing, certain/uncertain, credible/not credible, competent/incompetent. I reverse scored some of the items on both scales to protect against response bias. Higher numbers on the final scales represented more positive evaluations of the witnesses than did lower numbers.

Jurors also rated the trial using a series of 7-point Likert-type scales. The questionnaire can be found in Appendix B. Three separate scales were used to assess jurors' beliefs about the extent to which the plaintiff was forced to work in a hostile work environment, the plaintiff suffered, and the organization had an existing policy and 
responded to the allegations of sexual harassment. Participants were asked to indicate the extent to which they agreed with a number of statements. Specifically, statements on the hostile work environment scale included: the plaintiff worked in a hostile work environment at [the organization]; the pictures that hung at [the organization] are not appropriate for the workplace; no one should have to work in the environment described by the plaintiff; the plaintiff's coworkers' behavior was extremely offensive; the plaintiff was the victim of pervasive sexual harassment; sexual jokes, such as the ones made by the plaintiff's coworkers, are not acceptable in the workplace; the plaintiff's negative opinions of [the organization] result from the sexual harassment she experienced on the job; and, the male coworkers at [the organization] were joking with the plaintiff, not sexually harassing her (Chronbach's $\alpha=.92, \mathrm{n}=8$ ). Higher numbers indicated a more hostile work environment. Items on the scale that assessed the plaintiff's suffering asked jurors to rate the extent to which: the plaintiff experienced extreme pain and suffering because of the sexual harassment she experienced at [the organization]; the plaintiff suffered financially as a result of the sexual harassment she experienced at [the organization]; the plaintiff's work environment decreased the quality of her life; the sexual harassment experienced by the plaintiff had a severe impact upon her life; and, the plaintiff suffered severe emotional distress as a result of the sexual harassment she experienced (Chronbach's $\alpha=.94, n=5$ ). Higher numbers represented greater pain and suffering. The organizational policy and response scale included six questions that asked participants to indicate the degree to which they agreed with the following statements: [the organization] did not take precautions to prevent a hostile work environment; [the organization] took adequate preventative steps to ensure that employees did not work in a 
hostile work environment; the shift supervisor's response to the plaintiff's claims were inadequate; [the organization's] response to the plaintiff's complaints was extremely inadequate; an example should be made of [the organization] to discourage other companies from behaving in a similar manner; and, [the organization's] sexual harassment policies were intended to prevent sexual harassment in the workplace (Chronbach's $\alpha=.87, \mathrm{n}=6$ ). Higher numbers indicated that the company had done more, both proactively and reactively, to discourage sexual harassment.

Manipulation checks were incorporated into the questionnaire to be sure that the participants were cognizant of the manipulations. The severity manipulation check included four statements (Chronbach's $\alpha=.85$ ): the pictures hung at [the company] were not appropriate for the workplace; the plaintiff's coworkers' behavior was extremely offensive; the plaintiff was the victim of pervasive sexual harassment; and, sexual behaviors were pervasive throughout [the company]. Higher numbers indicate a stronger belief that the plaintiff experienced severe harassment. Five statements comprised the response manipulation check (Chronbach's $\alpha=.84$ ): the divisional director's response to the plaintiff's complaint was appropriate; [the company] did not take precautions to prevent a hostile work environment; [the company] took adequate steps to ensure that employees did not work in a hostile work environment; the shift supervisor's response to the plaintiff's claims was inadequate; and, [the company's] response to the plaintiff's complaints was extremely inadequate. Higher numbers on this scale indicated a stronger belief that the defendant had a prophylactic, effective sexual harassment policy. 
I recruited participants from potential jurors at the Broward County Courthouse, Seventeenth Judicial District in Fort Lauderdale, Florida. If participants chose to participate, they read a short summary of a sexual harassment trial and then answered a series of questions about the case. The experimenter did not reveal details of the case to participants in an effort to prevent potential sampling bias. The experimenter reminded all jurors that their participation was voluntary and that they may withdraw from the study at any time.

Interested jurors were provided with an informed consent for participation in the study. They then read a summary of a sexual harassment trial. The experimenter was blind to the participants' condition (i.e., pervasiveness of the sexual harassment and organizational policy and response). All versions of these summaries are in Appendix A. After participants read the trial summary, they returned the trial summary and were given the questionnaire (Appendix B). The experimenter debriefed all participants in private following completion of the questionnaire and answered all questions that the participants had at that time. All participants were treated in accordance with the ethical guidelines of the American Psychological Association (1992). 
Chapter Three: Results

\section{Data Analytic Strategy}

I analyzed all dependent measures using a 2 (Sexual Harassment Severity: Low vs. High) X 2 (Organization Policy: No Policy vs. Enforced Policy) analysis of variance (ANOVA). To normalize the distribution of the damage awards, I transformed participants' awards using a natural logarithm. For ease of comprehension, means are reported for the untransformed data. Damage awards for lost wages, future lost wages, medical expenses, and future medical expenses were combined to form one economic damage award. Pain and suffering damage awards comprised the other portion of compensatory damages. All three punitive damage awards (i.e., punish the defendant, deter the defendant, deter others) were combined to form one punitive damage award.

No interaction effects were found for harassment severity and organizational policy and response, all $F^{\prime} s<28.81$, all $\eta^{2}<.30$.

\section{Manipulation Checks}

The results of the ANOVA on the severity manipulation check indicated a main effect for the sexual harassment severity manipulation, $F(1,127)=31.00, p<.01, \eta^{2}=$ .20. Participants perceived that the harassment in the high severity trial stimulus was more severe than the harassment in the low severity trial stimulus $\left(M_{\text {High Severity }}=5.17\right.$; $M_{\text {Low Severity }}=3.78$ ).

When the ANOVA was run with the organizational policy and response manipulation check as the dependent variable, there was a main effect for organizational policy and response, $F(1,127)=50.77, p<.01, \eta^{2}=.30$. Participants perceived that the defendant's harassment policy was more effective and appropriate in the enforced policy 
conditions than in the no policy conditions $\left(M_{\text {Enforced Policy }}=5.08 ; M_{\text {No Policy }}=3.65\right)$.

Thus, the participants perceived both the severity and organizational policy and response manipulations as intended.

\section{Effects of Harassment Severity}

The results of the harassment severity manipulation are found in table 2 . Level of severity was found to effect damage awards for pain and suffering, $\eta^{2}=.06$. Participants made higher pain and suffering awards in the high severity condition than in the low severity condition. Harassment severity did not significantly influence economic or punitive damage awards at $p<.05$.

Participants who read the high severity trial stimulus rated the plaintiff's workplace as more hostile than did participants who read the low severity trial $\eta^{2}=.16$. Participants who read the high severity trial stimulus also were more likely to believe that the plaintiff should be compensated for her injuries than were participants who read the low severity stimulus $\eta^{2}=.14$. Participants in the high severity condition were also more likely to report that the organization should be punished than were participants in the low severity condition $\eta^{2}=.09$.

Participants in the high severity condition were also more likely to perceive the plaintiff as having been subjected to a hostile work environment than were participants in the low severity condition, $\eta^{2}=.19$. Participants who read the high severity vignette believed that the plaintiff had suffered more than did participants who read the low severity vignette, $\eta^{2}=.10$. Participants in the high severity condition judged the 
organization's policy and response to be less effective than did participants in the low severity condition, $\eta^{2}=.12$.

Table 2

The effects of harassment severity on dependant measures

Dependant Measures

High Low

$d f \quad$ Severity Severity $\quad F \quad p$

Economic damages

$125 \quad \$ 12,920 \quad \$ 7,211 \quad 3.37 \quad .07$

Pain and suffering damages

$125 \quad \$ 5,627 \quad \$ 2,066 \quad 7.93 \quad<.01$

Punitive damages

$126 \quad \$ 27,095 \quad \$ 16,718 \quad 3.01 \quad .09$

Did the plaintiff work in a HWE?

127

4.63

3.03

$24.13<.01$

Should the plaintiff be compensated for her injuries?

$\begin{array}{lllll}126 & 4.20 & 2.62 & 19.54 & <.01\end{array}$

Should the company be punished?

126

4.20

3.00

$11.72<.01$

Perceptions of a hostile work environment

$127 \quad 5.30$

$3.97 \quad 28.81<.01$

Perceptions of the plaintiff's suffering

$127 \quad 3.84$

2.82

$14.39<.01$

Perceptions of organizational policy

$127 \quad 4.67$

3.76

$17.23<.01$

and response

Note. Higher numbers indicate higher ratings in favor of the plaintiff. 
The effects of organizational sexual harassment policy and response are in table 3. There was a main effect of the organization's sexual harassment policy on punitive damage awards such that participants in the no enforcement condition conferred larger awards than participants in the enforcement condition, $\eta^{2}=.05$. There were no other significant effects of organizational policy on either economic or non-economic (i.e., pain and suffering) damage awards.

Participants in the no policy condition were more likely to believe that the organization should be punished than were participants in the enforced policy condition, $\eta^{2}=.08$. Participants in the no policy condition thought that the organization had made less of an attempt to respond to the plaintiff's complaints than did participants in the enforced policy condition, $\eta^{2}=.24$. Finally, there was a main effect for organizational policy on perceptions of suffering such that participants in the no policy condition felt that the plaintiff had suffered more than did participants in the enforced policy condition, $\eta^{2}=.06$. 
Table 3

The effects of organizational policy and response on dependant measures

\begin{tabular}{lcccccc}
\hline Dependant Measures & & No & Enforced & & \\
& $d f$ & Policy & Policy & & & $p$ \\
\hline Economic damages & 125 & $\$ 11,806$ & $\$ 8,325$ & 1.82 & .18 \\
Pain and suffering damages & 125 & $\$ 4,087$ & $\$ 3,606$ & $<.01$ & .97 \\
& & & & & & \\
Punitive damages & 126 & $\$ 36,510$ & $\$ 7,303$ & 2.41 & .02
\end{tabular}

Did the plaintiff work in a hostile work environment?

$\begin{array}{lllll}127 & 3.96 & 3.70 & .67 & .42\end{array}$

Should the plaintiff be compensated for her injuries?

$\begin{array}{lllll}126 & 3.64 & 3.18 & 1.61 & .21\end{array}$

Should the company be punished?

$\begin{array}{lllll}126 & 4.18 & 3.03 & 10.77 \quad<.01\end{array}$

$\begin{array}{llllll}\text { Perceptions of a hostile work environment } & 127 & 4.81 & 4.46 & 2.02 & .16\end{array}$

$\begin{array}{llllll}\text { Perceptions of the plaintiff's suffering } & 127 & 3.70 & 2.96 & 7.41 & <.01\end{array}$

Perceptions of the organizations' policy and response

$\begin{array}{lllll}127 & 4.89 & 3.53 & 38.60 & <.01\end{array}$

Note. Higher numbers indicate higher ratings in favor of the plaintiff. 
Path Models of Juror Decision Making in Sexual Harassment Cases

I hypothesized a sequential model for jurors' decision making in cases of hostile work environment sexual harassment (see Figure 1). My path model was developed using three exogenous variables: 1) organization's sexual harassment policy, 2) severity of the harassment, and 3) gender. I also included six endogenous variables in my model: 1) perceptions of organization policy and response, 2) perceptions of the plaintiff's suffering, 3) perceptions of a hostile work environment, 4) economic damage awards, 5) pain and suffering damage awards, and 6) punitive damage awards. I believe that the organization's sexual harassment policy, severity of the harassment, and gender will predict perceptions of the organization's policy and response, perceptions of plaintiff's suffering, and perceptions of a hostile work environment. In turn, I think that jurors' perceptions of the organization's policy and response, the plaintiff's suffering, and the extent to which the organization was a hostile work environment will predict economic damage awards, pain and suffering damage awards and punitive damage awards. I specified that perceptions of the organization's policy and response, the plaintiff's suffering, and the extent to which the organization was a hostile work environment would be correlated. I also specified that economic, pain and suffering, and punitive damage awards would be correlated. Pearson correlations for my model are presented in Table 4 below. 


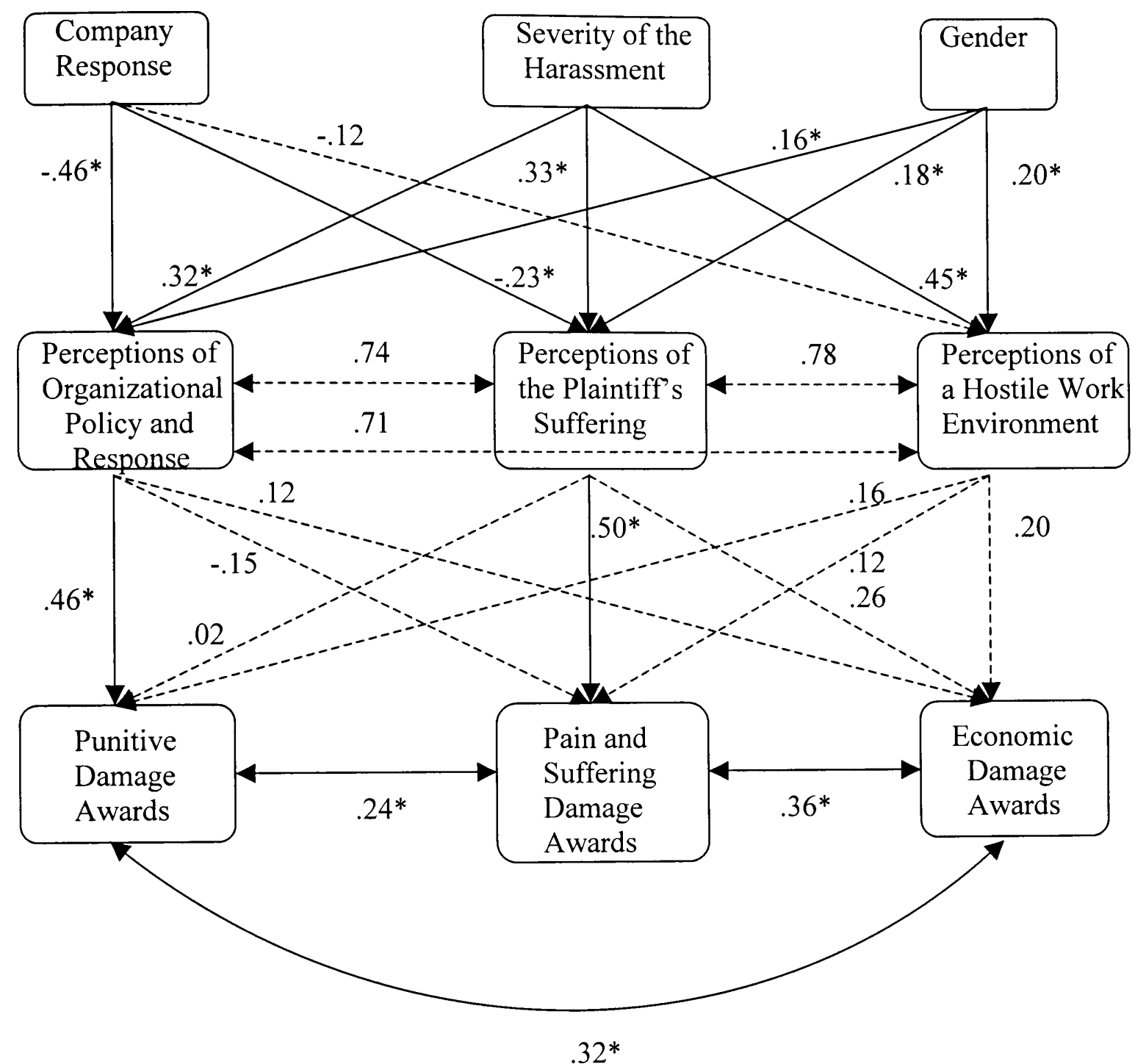

Figure 2. Path model of jurors' decision making in a hostile work environment sexual harassment case. Solid lines indicate a significant relationship and broken lines indicate a non-significant relationship. 
Table 4

Correlation Matrix for Mediating and Outcome Variables.

$\begin{array}{llllllll}\text { Variable } & 1 & 2 & 3 & 4 & 5 & 6\end{array}$

1. Perceptions of Response $\quad-\quad \begin{array}{llllll}.777 * & .724 * & .487 * & .289 * & .589 *\end{array}$

2. Perceptions of Suffering $\quad-\quad .812^{*} \quad .544^{*} \quad .460^{*} \quad .506 *$

3. Perceptions of Hostile Work $\quad-\quad .517^{*} \quad .391^{*} \quad .509^{*}$

Environment

4. Economic Damages

$-.493^{*} .537^{*}$

. Economic Damages

$-.377^{*}$

5. Punitive Damages

6. Pain and Suffering Damages

Note. $*$ Correlation is significant at the 0.01 level (2-tailed). 
The goodness-of-fit test, reported as a chi-square statistic, ${ }^{2}$ indicated that the model is a good fit to the data $\left(\chi^{2}(12)=8.66, p=.73\right)$. The normed fit index $(.98)$ and the comparative fit index (1.00) also demonstrated good fit. None of the standardized residuals exceed the established .10 standard. Ten of the eighteen model coefficients were statistically significant $(\mathrm{Zs}>1.96, p<.05)$. At the first level of the model, perceptions of the adequacy of the organization's response to the sexual harassment and perceptions of the plaintiff's suffering were predicted by gender, the severity of the harassment, and the organization's response to the harassment. Men believed that the organization's response was more adequate than women. Women were more likely to feel that the plaintiff had suffered than men. Perceptions of whether the plaintiff worked in a hostile work environment were only predicted by gender and the severity of the harassment. Women were more likely to find that the harassment suffered by the plaintiff resulted in a hostile work environment than were men. At the second level of the model, punitive damage awards were predicted by perceptions of the organization's response. Pain and suffering damage awards were predicted by perceptions of the plaintiff's suffering. There were no predictors of economic damages awards. Similarly, perceptions of whether the plaintiff worked in a hostile work environment were not predictive of any other variables.

\footnotetext{
${ }^{2}$ A goodness-of-fit test, reported as a chi-square statistic, is generally reported for the results of a path model. The goodness-of-fit test indicates how well the sample variance-covariance matrix is reproduced as a function of the parameter estimates of the proposed model. A chi-square statistic greater than the standard .05 criterion suggests that the model fits the data well. A statistically significant chi-square indicates that the model should be rejected. The chi-square statistic is sensitive to sample size and as such I also report the normed fit index (NFI) and the comparative fit index (CFI) as two additional indicators of model fit. Both indices can range from 0 to 1 , with models of .90 or greater being indicative of a good fit (Bentler, 1995).
} 
The primary goal of this study was to assess jurors' common understanding of sexual harassment through the damage awards they confer. I was also interested in whether jurors follow the law when making damage awards in sexual harassment cases. I predicted that jurors would comport with the law when conferring damage awards, but that this does not necessarily indicate that they understand the consequences of sexual harassment. I believed that jurors would award higher compensatory damages in cases of severe harassment than mild harassment. I also predicted that jurors would use information about the organization's sexual harassment policy and response when awarding punitive damage awards, though the awards returned may not be legally appropriate. I thought that companies who do not have a sexual harassment policy would be assessed higher punitive damages than organizations that have a prophylactic policy that is enforced. I believed that jurors would still assess punitive damages, however, on an organization that has a proactive, enforced policy. This, arguably, would be inappropriate given the Supreme Court ruling in Kolstad v. ADA (1999), which states that an organization that makes a good faith effort to prevent sexual harassment in the workplace cannot be assessed punitive damages as the result of the actions of one or more malicious employees.

Though jurors may confer legally appropriate damage awards, these awards may not reflect a common understanding of the consequences of sexual harassment. If the consequences of sexual harassment do not vary as a function of the harassment severity as research by Schnieder and her colleagues (1997) suggest, then differences in damage awards based on the perceived severity of the harassment would indicate that jurors do 
not understand sexual harassment. I predicted that although jurors would be able to apply the law when determining damage awards, they would not demonstrate an understanding of sexual harassment. I believed that their awards would differ as a function of how severe they perceive the harassment to be.

Research conducted to date on jurors' ability to award damages have used trial stimuli describing medical malpractice, personal injury and insurance bad faith cases. Initially, I thought that because cases involving medical malpractice, personal injury, and insurance bad faith all result in a physical injury that, as a result, the pain and suffering might be more tangible. If so, jurors would be able to separate injury severity from the defendant's behavior more easily in such cases than in sexual harassment cases. My results are consistent with the recent meta-analysis conducted by Wilbanks, Dunn, and Penrod (2002), which examined jurors damage awards in automobile negligence, medical malpractice, and product liability cases; case type did not affect jurors ability to award damages.

The Effects of Harassment Severity and Implications

As the law requires, jurors conferred higher pain and suffering compensatory damages when the plaintiff was a victim of severe harassment rather than mild harassment. Moreover, jurors' perceptions of the plaintiff's suffering mediated the effect of harassment severity on pain and suffering compensatory damage awards. This is consistent with previous research that found that injury severity influenced jurors compensatory, but not punitive, damage awards (Mott et al., 2000; Robbennolt \& Studebaker, 1999; Wissler et al., 1997). The lack of an effect of perceptions of the hostile work environment on damage awards provides further evidence that jurors are 
making good decisions (i.e., that they are not fusing liability and damages). Further, I believe that there was no effect of severity on economic damage awards because the amount requested by the plaintiff was held constant across conditions. This further indicates that jurors are awarding damages in a legally appropriate manner.

The harassment severity affected jurors' perceptions of the plaintiff's suffering. Previous research by Schneider and her colleagues (1997) raises questions about whether it is appropriate for harassment severity to affect perceptions of the plaintiff's suffering. Their research using actual victims of sexual harassment indicates that the severity of the sexual harassment does not predict the severity of the psychological harm experienced by the victim (Schneider et al., 1997). Sexual harassment that may be perceived as being mild has the same emotional consequences as more severe harassment (Schneider et al., 1997). Further research replicating Schneider and colleagues' findings is warranted to determine the emotional sequelae suffered by victims of sexual harassment. If the severity of harassment is not related to the degree of suffering experienced by sexual harassment victims, then it may be inappropriate for jurors to consider such information when formulating pain and suffering awards. Jurors would be making psychologically better decisions if they were to determine their pain and suffering awards by evaluating testimony about the emotional suffering endured by the plaintiff's rather than by considering information about the harassment itself.

Research indicating that even mild harassment results in severe consequences could be very valuable to plaintiffs' attorneys who are presenting cases in which jurors may perceive the alleged sexual harassment to be mild. Plaintiffs' attorneys may opt to call an expert on the consequences of sexual harassment to testify about the severe 
consequences that even mild sexual harassment may have on an individual. Plaintiff's attorneys would need to seriously consider the consequences such testimony may have (e.g. compelled mental health examinations) (Kovera \& Cass, 2002). Lawyers defending companies or individuals charged with sexual harassment could also benefit from this information. Attorneys representing defendants charged with severe harassment may be able to minimize damage awards by emphasizing the fact that severe and mild harassment have the same consequences for victims. It is not clear that this type of expert testimony would be admissible under Daubert v. Merrell Dow (1993) and Kumho Tire Company v. Carmichael (1998) as judges may either think that such information is commonsense and as such jurors do not need to be instructed on the consequences of sexual harassment or judges may believe that this information is not generally accepted in the field as it seems counterintuitive. Given research by Schneider and her colleagues (1997), the results of this study indicate that jurors do not have a common understanding of the consequences of sexual harassment.

Severity affected jurors' perceptions of the organization's sexual harassment policy and response to the alleged harassment such that when the harassment was more severe jurors thought that the organization responded less effectively than did jurors who read the mild harassment trial stimulus. It is possible that jurors do not perceive mild sexual harassment to be particularly damaging and as such, any amount of preventive policy or response to allegations of harassment seems sufficient. Jurors may, however, find severe sexual harassment to be extremely damaging and therefore see even an extreme response as inadequate in alleviating the damages endured by the plaintiff. It is also possible that jurors see a policy as ineffective when the harassment is severe because 
the policy was unable to prevent the severe harassment from occurring. Fitzgerald and her colleagues (1997) have shown that victims of sexual harassment who believe that their organization is not supportive suffer more severe damages from the harassment than victims who think their organization will support their claims of sexual harassment. As this study manipulated severity of harassment not injury severity, an interaction between perceptions of injury severity and organizational policy and response would have been expected to indicate that jurors understand this component of sexual harassment. Given that this interaction was not present, it appears that jurors are making legally inappropriate decisions by considering information about the harassment, not the consequences of the harassment, when determining damage awards.

Because jurors are likely to view an organization's response as being ineffective when the harassment in question was severe, plaintiff's lawyers would be best suited to emphasize the severity of the harassment in an effort to minimize the effect that the organization's response has on jurors' damage awards. If a plaintiff's attorney is successful in convincing jurors that the plaintiff suffered severe harassment, jurors may be likely to view the organization's response as insufficient and as such return larger damage awards than if they had seen the harassment as mild and the organization's response as effective. It is possible that attorneys' strategies currently follow such practices as a result of intuition rather than empirical facts. This result suggests that such litigation strategies may be beneficial.

Jurors' perceptions of an organization's response to sexual harassment as ineffective when the harassment is severe also has clear implications for organizations' policies. A prophylactic sexual harassment policy seems to be requisite for 
organizations. Executives in organizations need to ensure that sexual harassment training is required of all employees and that the administrators of the organization do not take that sexual harassment lightly. Similarly, executives need to react in a stern, definitive manner when responding to sexual harassment allegations, particularly when the complainants allege severe harassment. By reacting in such a manner, an organization would be able to provide documented proof that they made a good faith effort to prevent sexual harassment. Under Kolstad v. ADA (1999), a judge may then rule that the organization did everything in their control and cannot be assessed punitive damages as a result of the actions of one or more malicious employees. Given that Title VII is intended to encourage organizations to take a proactive attempt to prevent sexual harassment in the workplace, it is imperative that companies react in a documented, observable manner in order to minimize or prevent punitive damage awards.

Severity also affected whether jurors believed that the plaintiff was forced to work in a hostile work environment. The more severe the harassment was the more likely jurors were to perceive it as being a hostile work environment. This finding is inconsistent with past research demonstrating that any degree of sexual harassment is sufficient have psychological as well as physical and work-related consequences for the victim (Schneider et al., 1997). Although liability decisions were beyond the scope of this study, this finding has clear implications for real cases in which the jurors' task is to first determine whether the defendant is liable. If jurors are making legally appropriate decisions, then their verdicts should be determined by whether they find that the plaintiff worked in a hostile work environment. 
The Effects of Organizational Policy and Response and Implications

It is not surprising that the organization's sexual harassment policy and response to the plaintiff's allegations of sexual harassment predicted jurors' perceptions of the organization's response. Jurors perceived the organization to be less culpable when the organization had a proactive sexual harassment policy and responded in a timely, effective manner than when it had no prophylactic policy measures and did not respond forcefully. In addition, jurors' perceptions of the organization's actual response mediated the effect of organization response on punitive damages. This finding has interesting implications for organizations, not only in response to reports of sexual harassment but also when devising sexual harassment policies. Following Kolstad v. ADA (1999), many organizations, particularly universities, have recently enacted policies that mandate all employees participate in sexual harassment training in an attempt to minimize liability for punitive damages. This study provides empirical support that such practices may be effective at limiting punitive damages levied against defendants.

The organization's sexual harassment policy and response to the allegations of sexual harassment also predicted jurors' perceptions of the plaintiff's suffering. Jurors judged the plaintiff to have suffered greater harm when the organization did not respond to her claims of sexual harassment. This finding suggests that jurors may understand some of the factors that moderate a sexual harassment victim's psychological harm as it is consistent with research showing that a supportive organizational context minimizes the psychological damage from workplace sexual harassment (Driscoll, Worthington, \& Hurrell, 1995). This information would be beneficial to attorneys for both parties as well as for organizations when creating sexual harassment policies. Plaintiff's attorneys may 
want to stress any ineffective aspects of an organization's policy or response to allegations of sexual harassment. Defense attorneys, conversely, should emphasize any and all good faith attempts made by the organization to prevent and respond to claims of sexual harassment. Clearly, organizations need to be aware how critical a timely, effective response is in terms of the jurors' perceptions of the organization's legal obligation to the plaintiff. Organizations need also be cognizant of how essential measures aimed at preventing sexual harassment are in the event that sexual harassment allegations ever arise.

\section{Caveats}

This study assessed damage awards conferred by individuals rather than juries. Although juries decide sexual harassment cases and generally, the jury is responsible for assessing damages against the defendant when appropriate, I believe that it is important to examine the way in which individuals determine damage awards before examining how the process of deliberation alters individuals' awards. Research has shown that deliberations serve to increase ratings of blameworthiness and verdict size and as such, deliberations will only exacerbate potential errors in determining damage awards (Diamond \& Casper, 1992). Deliberations have not eradicated errors made by individual jurors (Greene, Johns, \& Bowman, 1999; Greene et al., 2001). An individual's determination of damage awards is also relevant in that there are numerous instances when judges, attorneys, and various other arbitrators must assign a monetary figure to the case.

The meta-analysis of juror damage awards conducted by Wilbanks and her colleagues (2002) found that college students tend to confer damage awards in a legally 
appropriate manner more often than their jury eligible counterparts. In the present study, $88 \%$ ( 111 of 126 participants) of the sample had at least some college education. If, as Wilbanks and her colleagues (2002) argue, educational level may moderate damage awards, then it may be warranted to reexamine this issue with a sample whose educational level is more representative of the national jury eligible population than this sample.

Another caveat is that this study employed written stimulus materials. A videotaped trial stimulus may be more ecologically valid than a written stimulus, but visual stimuli are not always possible. Given the regulations set forth by the Broward County Courts, a videotaped trial stimulus would not have been possible. As such, this study would have had to been conducted with undergraduates as participants. I believed that using potential jurors was preferable to using undergraduates psychology students. A strength of this study is that is assesses the way in which actual jurors may think about a sexual harassment case prior to deliberations. It is possible that in contrast to the metaanalysis conducted by Wilbanks and her colleagues (2002), which did not look at decisions in sexual harassment cases, that student populations would legally inappropriate decisions as compared with their actual juror counterparts. Students are less likely to have experience with sexual harassment in general as well as with the consequences associated with such harassment. Undergraduate students are unlikely to have undergone sexual harassment training and may not know what behavior is typical and expected in a workforce. Students may also see the plaintiff as more able to find a new job as a result of the relative ease with which most college students are able to find employment upon graduation. 


\section{Conclusion}

Overall, the current study found that jurors followed the law when awarding damages. In addition to considering legally relevant factors when deciding pain and suffering awards, jurors' did not consider irrelevant factors. That is, jurors did not consider the organization's response when determining both the economic and pain and suffering components of compensatory damages. Jurors used information about the organization's response when awarding punitive damages but appropriately disregarded information about the plaintiff's emotional suffering. It is not surprising that there were no effects for the severity of the harassment or the organization's response on the economic component of compensatory damages as the plaintiff requested the same amount in all scenarios.

As the number of sexual harassment cases grows, the need to understand how jurors confer awards becomes increasingly critical. Damage awards calculated in a legally inappropriate manner clearly raise serious issues for both plaintiffs and defendants: plaintiffs may not be awarded pain and suffering damages indicative of their suffering or organizations may be assessed punitive damages that are not in accord with their behavior. Egregious errors in damage awards are also problematic in that these errors can serve to decrease public confidence in the legal system. The results of this study, indicating that jurors are awarding damages in a legally appropriate manner, may restore critics' confidence in the legal system and particularly in juries. Jurors' abilities to appropriately award damages may also provide insight into how jurors make decisions in other types of discrimination cases, particularly employment discrimination cases. 
This study contributes to the growing body of research investigating civil juror's decisions. 


\section{References}

American Psychological Association. (1992). Ethical principles of psychologists and code of conduct. American Psychologist, 47, 1597-1611.

Anderson, M.C., \& MacCoun, R.J. (1999). Goal conflict in juror assessments of compensatory and punitive damages. Law and Human Behavior, 23 (3), 313-330.

Andrew, M.J., \& Andrew, J.D. (1997). Sexual harassment part 2: Employer liability. Journal of Rehabilitation Administration, 21(2), 79-92.

Bentler, P.M. (1995). EQS: Structural equations program manual. Los Angeles, CA: BMPD Statistical Software.

Bornstein, B.H. (1994). David, Goliath, and Reverend Bayes: Prior beliefs about defendant's status in personal injury cases. Applied Cognitive Psychology, 8 (3),_233258.

Brooks, L., \& Perot, A.R., (1991). Reporting sexual harassment: Exploring a predictive model. Psychology of Women Quarterly, 15 (1), 527-547.

Cather, C., Greene, E., \& Durham, R. (1996). Plaintiff Injury and defendant reprehensibility: Implications for compensatory and punitive damages. Law and Human Behavior, 20 (2), 189-205.

Civil Rights Act of 1991. P.L. 102-106, U.S. Code 1981 nt.

Cochran, C.C., Frazier, P.A., \& Olson, A.M. (1997). Predictors of responses to unwanted sexual attention. Psychology of Women Quarterly, 21 (2), 207-226.

Crull, P. (1982). Stress effects of sexual harassment on the job: Implications for counseling. American Journal of Orthopsychiatry, 52 (3), 539-544.

Cross v. State of Alabama, 49 F.3d 1490 (1995).

Daubert v. Merrell Dow, 509 U.S. 579, 113 S.Ct. 2786 (1993).

Diamond, S.S., \& Casper, J.D. (1992). Blindfolding the jury to verdict consequences: Damages, experts, and the civil jury. Law and Society Review, 26 (3), 513-563.

Driscoll, R.J., Worthington, K.A., \& Hurrell, J.J. (1995). Workplace assault: An emerging job stressor. Consulting and Psychology: Practice and Research, 47 (4), $205-$ 211. 
Ellison v. Brady, 924 F.2d 872, 878-881 (1991).

Feigenson, N., Park, J., \& Salovey, P. (1997). Effect of blameworthiness and outcome severity on attributions of responsibility and damage awards in comparative negligence cases. Law \& Human Behavior, 21(6), 597-617.

Fitzgerald, L.F., Drasgow, F., Hulin, C.L., Gelfand, M.J., \& Magley, V.J. (1997). Antecedents and consequences of sexual harassment in organizations: A test of an integrated model. Journal of Applied Psychology, 82 (4), 578-589.

Fitzgerald, L.T., Hulin, C.L., \& Drasgow, F. (1994). The antecedents and consequences of sexual harassment in organizations: An integrated model. In G.P. Keita \& J.J. Hurrell, Jr. (Eds.), Job stress in a changing workforce: Investigating gender, diversity, and family issues. Washington, DC: American Psychological Association.

Goldenhar, L.M., Swanson, N.G., Hurrell, J.J., Ruder, A., \& Deddens, J. (1998). Stressors and adverse outcomes for female construction workers. Journal of Occupational Health Psychology, 3 (1), 19-32.

Goodman, J., Loftus, E.F., Miller, M., \& Greene, E. (1991). Money, sex, and death: Gender bias in wrongful death damage awards. Law \& Society Review, 25 (2), 263-285.

Goodman-Delahunty, J., \& Foote, W.E. (1995). Compensation for pain, suffering, and other psychological injuries: The impact of Daubert on employment discrimination claims. Behavioral Sciences \& the Law, 13(2), 183-206.

Greene, E., \& Goodman-Delahunty, J. (1995). Diagnosis of psychological impairment in employment discrimination claims. Behavioral Sciences and the Law, 13, 459-476.

Greene, E., Johns, M., \& Smith, A. (2001). The effects of defendant conduct on jury damage awards. Journal of Applied Psychology, 86 (2), 228-237.

Greene, E., \& Loftus, E.F. (1998). Psycholegal research on jury damage awards. Current Directions in Psychological Science, 7 (2), 50-54.

Greene, E., Woody, W.D., \& Winter, R. (2000). Compensating plaintiffs and punishing defendants: Is bifurcation necessary? Law and Human Behavior, 24 (2), 187 205.

Gutek, B.A. (1985). Sex and the workplace. San Francisco: Jossey-Bass. 
Gutek, B.A., \& Done, R.S. (2001). Sexual harassment. In R.E. Unger (Ed.). Handbook of the psychology of women and gender. New York, NY: John Wiley \& Sons, Inc.

Gutek, B. A., O’Connor, M. A., Melançon, R., Stockdale, M. S., Geer, T. M., \& Done, R.S. (1999). The utility of the reasonable woman legal standard in hostile environment sexual harassment cases. A multimethod, multistudy examination. Psychology, Public Policy, and Law, 5, 596-629.

Hall v. Gus Construction Co., 842 F.2d 1010 (1988).

Hans, V.P. (2000). Business on trial: The civil jury and corporate responsibility. Newark, DE: University of Delaware Press.

Harris v. Forklift Systems, Inc., 510 U.S. 17, 114 S.Ct. 367 (1993).

Hastie, R., Schkade, D.A., \& Payne, J.W. (1999). Juror judgments in civil cases: Effects of plaintiff's requests and plaintiff's identity on punitive damage awards. Law and Human Behavior, 23 (4), 445-470.

Hurt, J.L., Maver, J.A., \& Hofman, D. (1999). Situational and individual influences on judgments of hostile work environment sexual harassment. Journal of Applied Social Psychology, 29 (7), 1395-1415.

Kolestad v. ADA, 527 U.S. 526; 119 S.Ct. 2118 (1999).

Koss, M.P. (1990). Changed lives: The psychological impact of sexual harassment. In Paludi, M.A. (Ed.) (1990). Ivory power: Sexual harassment on campus. New York: State University of New York Press.

Kovera, M.B., \& Cass, S.A. (2002). Compelled mental health examinations, liability decisions, and damage awards in sexual harassment cases: Issues for jury research. Psychology, Public Policy, \& Law, 8 (1), 96-114.

Kovera, M.B., McAuliff, B.D., \& Hebert, K.S. (1999). Reasoning about scientific evidence: effects of juror gender and evidence quality on juror decisions in a hostile work environment case. Journal of Applied Psychology, 84, 362-375.

Kumho Tire Company v. Carmichael, 526 U.S. 137, 119 S.Ct. 1167 (1998).

Langhout, R.D., Bergman, M.E., Cortina, L.M., Fitzgerald, L.F., Drasgow, F., \& Hunter Williams, J. (1999). Women's experiences of sexual harassment: A closer look. Paper presented at the $14^{\text {th }}$ annual meeting of the Society for Industrial and Organizational Psychology, Atlanta, GA. 
MacCoun, R.J. (1996). Differential treatment of corporate defendants by juries: An examination of the "deep pockets" hypothesis. Law \& Society Review, 30(1), 121161.

McAuliff, B. D., \& Kovera, M. B. (2001). Need for cognition and juror sensitivity to methodological flaws in psychological science. Manuscript submitted for publication.

Meritor Savings Back v. Vinson, 477 U.S. 57, 106 S.Ct. 2399 (1986).

Mott, N.L., Hans, V.P., \& Simpson, L. (2000). What's half a lung worth? Civil jurors' accounts of their award decision making. Law and Human Behavior, 24, 401419.

O'Connell, C.E., \& Korabik, K. (2000). Sexual harassment: The relationship of personal vulnerability, work context, perpetrator status, and type of harassment to outcomes. Journal of Vocational Behavior, 56, 299-329.

Robbennolt, J.K. \& Studebaker, C.A. (1999). Anchoring in the courtroom: The effects of caps on punitive damages. Law and Human Behavior, 23 (3), 353-372.

Robinson v. Jacksonville Shipyards, Inc., 760 F. Supp. 1486. (M.D. Fla. 1991).

Saks, M.J., Hollinger, L.A., Wissler, R.L., Evans, D.L., \& Hart, A.J. (1997). Reducing variability in civil jury awards. Law and Human Behavior, 21 (3), 243-256.

Schneider, K.T., Swan, S., \& Fitzgerald, L.F. (1997). Job-related and psychological effects of sexual harassment in the workplace: Empirical evidence from two organizations. Journal of Applied Psychology, 82 (3), 401-415.

Sheffy, S., \& Tindale, R.S. (1992). Perceptions of sexual harassment in the workplace. Journal of Applied Social Psychology, 22 (19), 1502-1520.

Terpstra, D.E., \& Cook, S.E. (1985). Complainant characteristics and reported behaviors and consequences associated with formal sexual harassment charges. Personnel Psychology, 38 (3),_559-574.

Thacker, R.A. (1996). A descriptive study of situational and individual influences upon individuals' responses to sexual harassment. Human Relations, 49 (8), 1105-1122.

Vidmar, N., Lee, J., Cohen, E., \& Stewart, A. (1994). Damage awards and jurors' responsibility ascriptions in medical versus automobile negligence cases. Behavioral Sciences and the Law, 12 (2), 149-160. 
Webb, S.L. (1994). Shockwaves: The global impact of sexual harassment. New York: Master Media Limited.

Wiener, R.L., Hurt, L., Russell, B., Mannen, K., \& Gasper, C. (1997).

Perceptions of sexual harassment: The effects of gender, legal standard, and ambivalent sexism. Law and Human Behavior, 21, 71-93.

Wiener, Watts, Goldkamp, \& Gasper, (1995). Social analytic investigation of hostile work environments: A test of the reasonable woman standard. Law and Human Behavior, 19 (3), 263-281.

Wilbanks, J.C., Dunn, K.F., \& Penrod, S.D. (2002, March). The appropriateness of civil juror decisions: A meta-analysis of civil jury decision making. Paper presented at the biannual meeting of the American Psychology-Law Association, Austin, TX.

Wissler, R.L., Evans, D.L., Hart, A.J., Morry, M.M., \& Saks, M.J. (1997). Explaining "pain and suffering" awards: The role of injury characteristics and fault attributions. Law and Human Behavior, 21 (2), 181-207.

Yoder, J.D., \& Aniakudo, P. (1995). The responses of African American women firefighters to gender harassment at work. Sex Roles, 32, 125-137.

Zickafoose, D.J., \& Bornstein, B.H. (1999). Double discounting: The comparative negligence on mock juror decision making. Law and Human Behavior, 23 (5), 577-596. 
Appendix A

[severity and frequency manipulation indicated in bold type; organization response manipulation indicated with italicized type]

\section{IN THE PINELLAS COUNTY SUPERIOR COURT \\ FOR THE STATE OF FLORIDA}

$\begin{array}{ll}\text { Sarah Hubbard } & \text { ) } \\ \text { Plaintiff } & \text { v. } \\ & \text { ) } \\ \text { Sunshine Trucking Company } & \text { ) } \\ \text { Defendant } & \end{array}$

SUMMARY OF

TRIAL PROCEEDINGS FROM

\section{Opening Statement from Plaintiff's Attorney}

The plaintiff, Sarah Hubbard, alleges that she is the victim of sexual harassment due to the hostile work environment at her place of employment, Sunshine Trucking Company (STC). Ms. Hubbard will describe the offensive behavior of her co-workers and the sexually explicit material posted in the workplace. She will also describe the emotional suffering she has experienced due to the harassment. Finally, STC employee, Nancy Peters, will also describe the sexualized behavior of the male employees of STC.

\section{Opening Statement from Defendant's Attorney}

Sunshine Trucking Company is not a hostile working environment. The management of STC has provided a supportive working environment for all employees by responding forcefully to unacceptable behavior exhibited by any of its employees. In contrast, the defense will show that Ms. Hubbard is an overly sensitive employee and has a history of poor relationships with her male co-workers.

\section{THE PLAINTIFF'S CASE}

Testimony of Ms. Sarah Hubbard, the plaintiff

On direct examination, Ms. Hubbard stated that she has worked at Sunshine Trucking for ten years. She testified that she works with a team of mechanics servicing the company's fleet of vehicles. The rest of the team members are men. She claimed that the atmosphere in the workplace makes it difficult for her to do her job well.

She complained that pictures of scantily clad [nude] women periodically hung in [hung all over the] the workplace. She identified Exhibit \#1, a swimsuit calendar manufactured by a tool company, as some of the material displayed in the garage at STC. 
The calendar contained pictures of extremely large breasted women in very revealing thong [see-through] bikinis. The women posed provocatively with the tools [some of them appeared to be engaging in sexual acts with the tools]. Ms. Hubbard claimed that this calendar was representative of the type of sexually suggestive material displayed in the workplace at STC. The plaintiff described several other sexually suggestive posters that also hung in various work areas (in the lunch room, over the time clock). One poster depicted an extremely large breasted woman in a skimpy [thong] bikini. The woman had the phrase "U.S.D.A. Prime Beef" printed across her stomach.

Ms. Hubbard also testified that her co-workers made crude comments about sex and women in her presence on a couple of occasions [and frequently her coworkers directed these comments at her]. She described one incident in particular detail. She testified that one day when she and many of her co-workers were in the lunchroom, one of the other mechanics, Jerry Fraser, sat down at the lunch table and began telling sexual jokes [entered the room with a wrench or a flashlight down his pants to look like he had an erection or a big penis. He approached her and in front of everybody asked, "how'd you like to get your hands on this tool, sweetie?"]. The plaintiff testified that she was embarrassed and humiliated, and got up right away to leave the room. All the men in the room were laughing and cheering him on. [At other times, her coworkers brushed up against her breasts and buttocks and said things like, "come on, you know you want it."] She also testified that her male coworkers asked her to join in once or twice when they described their recent sexual activities. [Her male coworkers frequently asked her to describe her recent sexual activities and often called her offensive names like "slut" and "whore". Ms. Hubbard testified that incidents, such as the one she just described, as well as sexual comments directed at her, occurred on almost a daily basis.]

The plaintiff voiced her discomfort to her shift supervisor and to the director of the maintenance operation at STC. The plaintiff reported her supervisors promised to remove the photos but the photos never were [The plaintiff reported her supervisors removed the photos immediately, but the pictures always returned after a week or two]. Jerry Fraser was never reprimanded for his behavior.

The plaintiff testified that she became so depressed and demoralized that she found it difficult to go to work. She always turned down overtime so that she could spend as little time in the workplace as possible. She missed a total of 162 days at work over a period of six years. The plaintiff testified that she was absent on these days because the hostile working conditions at STC damaged her psychological and physical health. Ms. Hubbard estimates that she lost close to $\$ 14,000$ for the missed days and another $\$ 11,000$ in overtime pay. She also testified that she spent $\$ 1,500$ for appointments with a psychiatrist and an additional $\$ 750$ on medication not covered by her insurance.

On cross-examination, the defense attorney asked Ms. Hubbard whether she had ever had any problems similar to the ones she claims to have experienced at STC. She 
responded that she had filed a sexual harassment claim against one of her co-workers at Florida Citrus Distributors because he kept asking her for dates even after she had refused him. The defense attorney also uncovered that Ms. Hubbard had not made any reports of unwelcome sexual activity until more than one year after Ms. Hubbard alleged that the unwelcome behavior began. The plaintiff also acknowledged that she frequently used profane language while at work. [Ms. Hubbard also admitted that only a few pictures, such as the ones she described, hung at any given time and that they were generally only present for a few days when the men first received them. She also testified that incidents, like the one involving Jerry Fraser, as well as the sexual comments in her presence were rare.]

The defense attorney also inquired about the reasons for Ms. Hubbard's absences from work. Ms. Hubbard admitted to lying to her employers about the reasons for her absences, claiming that she was sick rather than complaining about her working conditions. Ms. Hubbard also admitted that she worked as a massage therapist during the time that she was absent from work at STC.

\section{Testimony of Ms. Nancy Peters, STC employee}

During direct examination, Ms. Peters stated that she has worked in the Purchasing Department at STC for eight years. She explained that she is responsible for maintaining the inventory of parts needed by the mechanics to repair STC's trucks. Her duties cause her to be in the garage area where the plaintiff works at least once a week. Ms. Peters reported that she had also witnessed the sexually suggestive photographs posted in the workplace. She identified Exhibit \#1 (the swimsuit calendar) as one of the suggestive pictures that she had seen in the garage. She testified that she had seen similar material in the lunchroom and over the time clock.

[Ms. Peters also testified that she had witnessed the male mechanics harassing the plaintiff. They whistled at Ms. Hubbard and made obscene gestures behind her back. Ms. Peters also reported seeing a couple of men thrusting their hips forward and grabbing their groins as the plaintiff walked past.]

On cross-examination, Ms. Peters admitted it was possible that the plaintiff had never indicated that she disapproved of the photos and sexual jokes, but that she had no way of knowing for sure because she was not in the garage area that often. She testified that she has not witnessed Jerry Fraser's alleged act. Ms. Peters also testified that the male mechanics had never made any inappropriate sexual gestures or comments to her personally. Finally, she testified that the sexually suggestive pictures present in the workplace did not make her feel uncomfortable, [but she stressed that she was not in the area that often].

After this testimony, the plaintiff rested her case. 


\section{THE DEFENDANT'S CASE}

Testimony of Mr. John Thomas, STC employee

On direct examination, Mr. Thomas, a shift supervisor in the maintenance garage at STC testified that he was the plaintiff's direct supervisor and worked in the same garage as the plaintiff on a daily basis. Mr. Thomas testified that although the plaintiff was an excellent mechanic, she was unreliable. She was often absent from work. If she did show up for work, she came in late or left early. As her supervisor, Mr. Thomas had to write her up for her many absences and Ms. Hubbard received a reprimand from Personnel. She made her claims of sexual harassment soon after this incident.

Mr. Thomas also testified that the plaintiff had difficulty getting along with other people. He reported that she is generally irritable and lets things get under her skin too easily. He also noted that the plaintiff had been working at the garage for four years, in the presence of the pictures of scantily clad women, yet she only commented once to him about their content. Mr. Thomas testified that he never removed the pictures because he was busy with other tasks that were critical to smooth operations at STC. He stated that was a shift supervisor not a babysitter, and that it was not his job to ensure that the mechanics were not upsetting the plaintiff [Mr. Thomas testified that he removed the pictures immediately]. He also testified that he never saw the other mechanics act inappropriately toward Ms. Hubbard, except for the occasional use of profanity. Mr. Thomas testified that he did nothing to stop the profanity because the plaintiff often used foul language herself, and she had never complained about profanity in the workplace.

On cross-examination, Mr. Thomas admitted that he had promised Ms. Hubbard that he would remove the pictures, but that he had but that he had had become busy with other tasks and had simply forgotten [Mr. Thomas admitted that even though he removed the pictures after Ms. Hubbard complained, this type of material did have a tendency to reappear]. Mr. Thomas admitted that it was possible that incidents like the one the plaintiff reported Jerry Fraser committed may have occurred and may have been offensive to Ms. Hubbard, but that he had no way of judging for himself because he did not witness the event.

\section{Testimony of Mr. Michael Richards, STC employee}

On direct examination, Mr. Richards testified that he was the Director of Fleet Maintenance at STC. He is responsible for supervising the 15 shift supervisors and all of the mechanics who work in the STC garage. He testified that he met with the plaintiff to discuss her complaints about the sexualized materials in the garage at STC. During this meeting, the plaintiff produced an example of the type of sexualized material that offended her - a magazine advertisement in which a woman was wearing jeans but no shirt. Her arms were covering her bare breasts. She also produced a beer advertisement that contained the "Swedish Bikini Team"--three blond large-breasted women in [seethrough] bikinis. [Mr. Richards testified that the women in these ads were not 
engaging in any type of sexual activity nor were they nude. He characterized the material as something you might see on TV every night. Mr. Richards testified that because Ms. Hubbard was complaining about photos that were in no way pornographic or sexually explicit, he did not believe that they could contribute to a hostile work environment.] [Mr. Richards testified that the pictures were immediately removed following her complaint.] He also noted that no other women had filed either informal or formal complaints about the photos or about male co-workers engaging in inappropriate sexual behavior. [Mr. Richards also testified that, for the past five years, all STC employees were required to participated in sexual harassment training as a condition of employment.]

Mr. Richards also testified that he became aware of the plaintiff's complaints about the men's sexualized behavior in her presence during this meeting [including the incident when one of her coworkers approached her while simulating an erection]. He explained that he offered to follow-up the plaintiff's complaints with an investigation but that she was unable to provide him with details of specific incidents as well as the names of specific individuals who were involved in those incidents. Therefore, he was unable to investigate her complaints. [He explained that despite the plaintiff's inability to provide him with details of specific incidents as well as the names of specific individuals who were involved in those incidents, he was able to determine who simulated an erection. As a result of his involvement in that incident, STC suspended Jerry Frazier without pay for one day and required to take a sensitivity training course. Mr. Richards testified that he also distributed a memo to all employees stating STC's sexual harassment policy. He also held a meeting with the mechanics working in the garage during which he asked the men to be sensitive of their female coworkers.]

On cross-examination, Mr. Richards testified that he spend very little time in the garage area where the plaintiff worked, therefore, he had no knowledge of the types of behavior that were typical in the garage at STC. He also admitted that STC did not require its employees to participate in sexual harassment training, nor did STC make such training available.

After this testimony, the defendant rested its case.

\section{Plaintiff attorney's summation}

During closing arguments, the plaintiff's attorney concluded that Ms. Hubbard was subjected to a hostile work environment at the STC garage. He reminded the jury that several witnesses (Sarah Hubbard, Nancy Peters, and John Thomas) had testified that pictures of scantily clad women hung in the garage and in the lunchroom.

The plaintiff's attorney also reminded the jury that Ms. Hubbard described her coworkers' sexually inappropriate behavior, [including the incident during lunch when one of her coworkers approached her and her coworkers while simulating an erection]. He argued that the hostility of this work environment caused the plaintiff so 
much stress and anxiety that she became physically unable to perform her job. As a result of this abusive treatment, the plaintiff lost wages and opportunities to work overtime; she deserves compensation for her losses.

The attorney stated that the laws of this country state that all people should be entitled to work in an environment in which they are free from the type of abusive behavior Ms. Hubbard experienced; all people should be free from sexual harassment. These laws do not require that the victim quit her job to avoid the abuse. These laws do not require that the victim be coerced into engaging in sexual activity to maintain her employment or to receive some job benefit. All that must be proved is that the victim's work environment was hostile. The abusive behavior directed toward Ms. Hubbard was persistent and pervasive, and the behavior was clearly unwelcome. It caused her a significant amount of stress, so much that she was unable to attend work at times. The abusive behavior clearly changed the tenor of the work environment and detrimentally influenced Ms. Hubbard's work performance. The attorney concluded that the evidence proves that STC is a hostile work environment. Ms. Hubbard is entitled to damages to compensate her for lost wages. Moreover, punitive damages should be assessed against STC so that this company is sent a clear message that this type of work environment is unconscionable and will not be tolerated.

\section{Defense attorney's summation}

During her closing arguments, the defense attorney argued that Ms. Hubbard's behavior is not consistent with the behavior of someone who is being sexually harassed. She claims that the plaintiff is unable to work because of the stress and anxiety she has been caused while working at STC, yet she continues to work as a massage therapist during her absences from STC. Ms. Hubbard says that the sexual behavior of her coworkers and the posters that are on the wall offends her. Yet, her supervisor, Mr. Thomas, testified that she worked in the presence of the posters for years before complaining about them. He also noted that her complaints arose only after he reprimanded her for her frequent absences from work. The defense attorney reminded the jurors that the plaintiff herself admitted that she often used profanity. The defense attorney also reminded the jury that the plaintiff has a consistent record of problems on the job with her male co-workers. The attorney suggested that the plaintiff is overly sensitive and has a chip on her shoulder rather than a victim of sexual harassment.

The defense attorney argued that STC has made an effort to make their workplace friendly to women. Indeed, the plaintiff is the only woman ever to file a sexual harassment complaint at STC. The defense attorney also reminded jurors that STC management quickly responded to the plaintiff's complaints by evaluating the alleged sexual pictures before deeming that these pictures were not sexually offensive and as such did not need to be removed. Mr. Richards offered to investigate the alleged incident but was unable to take action because the plaintiff could not provide the names of the men who allegedly harassed her. [The defense attorney reminded jurors that STC management quickly responded to the plaintiff's complaints by removing the alleged 
sexual pictures. Mr. Richards also investigated the alleged incident between Jerry Frazier and the plaintiff. STC suspended Mr. Frazier from work for one day and required him to take a sensitivity training course, despite his claims that the incident never occurred.] Management contends that she would not, rather, could not provide the names because these incidents never happened. [Despite Management's doubts, they held a meeting with mechanics reminding them to be sensitive to their female coworkers and circulated a memo stating the company's policy on sexual harassment.]

In closing, the defense attorney argued that the plaintiff failed to provide sufficient evidence for the jury to conclude that the maintenance garage at STC was a hostile work environment. She argued that the lack of evidence and the inconsistency of the plaintiff's allegations suggest that the jury should find STC not liable of promoting a hostile work environment.

\section{$\underline{\text { Judge's instructions }}$}

The plaintiff has alleged that she has been forced into a hostile work environment because of sexual harassment. To establish this claim of environmental sexual harassment against defendants, plaintiff must prove, by a preponderance of the evidence, each of the following elements:

(1) That the plaintiff was subject to unwelcome sexual harassment;

(2) That the harassment complained of was based upon sex;

(3) That the harassment complained of was sufficiently severe or pervasive so as to alter the conditions of employment and create a hostile or abusive working environment; and

(4) That plaintiff suffered injury, damage, or harm, which was caused by the sexual harassment.

The harassment must be unwelcome and hostile. In determining whether the conduct was unwelcome, you should consider all the evidence and base your decision on it. In determining whether the conduct is hostile, the harassment must be sufficiently severe or extensive to alter the conditions of the plaintiff's employment and to create an abusive work environment.

In determining whether a hostile work environment existed, you must consider the evidence from the perspective of a reasonable person. This is an objective standard, and you must look at the evidence from the perspective of a reasonable person's reaction to a similar environment under similar circumstances. You cannot view the evidence from the perspective of an overly sensitive person. Rather, you must evaluate the total circumstances and determine whether the alleged harassing behavior could be objectively classified as the kind of behavior that would seriously affect the psychological well-being of a reasonable person.

Preponderance of the evidence is not the same as beyond a reasonable doubt. A preponderance of the evidence simply means evidence that persuades you that the 
plaintiff's claim is more likely to be true than not to be true. If the proof fails to establish any essential part of the plaintiff's claim by a preponderance of the evidence, you should find for the defendant as to that claim.

If you find that the defendant is liable to the plaintiff, then you must determine an amount that is fair compensation for all of the plaintiff's damages. The purpose of compensatory damages is to make the plaintiff whole - that is, to compensate the plaintiff for the damage that the plaintiff has suffered.

If you find that the defendant is liable for the plaintiff's injuries, you must award the plaintiff the compensatory damages that she has proven. You also may award punitive damages, if the plaintiff has proved that the defendant acted with malice or willfulness or with callous and reckless indifference to the safety or rights of others. If you determine that the defendant's conduct was so shocking and offensive as to justify an award of punitive damages, you may exercise your discretion to award those damages. In making any award of punitive damages, you should consider that the purpose of punitive damages is to punish a defendant for shocking conduct, and to deter the defendant and others from engaging in similar conduct in the future.

A person who claims damages resulting from the wrongful act of another has a duty under the law to use reasonable diligence to mitigate - to avoid or minimize those damages. If you find the defendant is liable and the plaintiff has suffered damages, the plaintiff may not recover for any item of damage, which she could have avoided through reasonable effort. If you find by a preponderance of the evidence the plaintiff unreasonably failed to take advantage of an opportunity to lessen her damages, you should deny her recovery for those damages, which she would have avoided had she taken advantage of the opportunity. 
In a previous phase of the trial, jurors found for the plaintiff (Sarah Hubbard), stating that Ms. Hubbard had proved that the defendant (Sunshine Trucking Company) was liable.

In this case, you may (but you are not required to) award the plaintiff (Sarah Hubbard) compensatory damages.

Please indicate the amount of money you would award the plaintiff to compensate her.

For lost wages to the date of the trial

For estimated future lost wages

For medical \& psychiatric expenses to trial date

For estimated future medical \& psychiatric expenses

For pain and suffering

In this case, you may (but you are not required to) award the plaintiff (Sarah Hubbard) punitive damages.

Please indicate the amount of money you would award the plaintiff to punish the defendant and/or deter other companies from engaging in similar practices.

To punish the defendant

To deter the defendant from engaging in similar practices

To deter others from engaging in similar practices

Instructions: Please indicate, on the following 7-point scales, the extent to which you agree with the following statements.

Ms. Hubbard was the victim of hostile work environment sexual harassment.

$\begin{array}{ccccccc}1 & 2 & 3 & 4 & 5 & 6 & 7 \\ \text { STRONGLY } & & & & & & \text { STRONGLY } \\ \text { DISAGREE } & & & & & & \end{array}$

Ms. Hubbard should be compensated for her injuries.

ONGLY

3

4

5

6

7

STRONGLY

DTRONGLY

AGREE

Sunshine Trucking Company should be punished for its conduct.

ONGLY

3

4

5

6

7

STRONGLY

AGREE

DISAGREE 
Next, we would like you to describe your impressions of the testimony that you read. Please rate each witness using a series of adjectives. The scales are designed so that you can express the degree to which the person seems to fit one end of the scale or the other. The space you check should depend on the degree to which the word describes the person. For example, if you thought Ms. Hubbard was slightly tall, you would mark:

\section{Tall}

$\mathrm{X}$

Short

However, if you thought that Sarah was extremely short, you should place the " $\mathrm{X}$ " next to short:

\section{Tall}

\begin{tabular}{|l|l|l|l|l|}
\hline & & & $\mathrm{X}$ & Short \\
\hline
\end{tabular}

Based on the testimony that you read, carefully rate your impressions of Sarah Hubbard (the plaintiff) as best you can on each of the following dimensions:

\begin{tabular}{|l|l|l|l|l|l|l|l|l|}
\hline Immoral & & & & & & & & Moral \\
\hline Respectable & & & & & & & & Not respectable \\
\hline Intelligent & & & & & & & & Unintelligent \\
\hline Good & & & & & & & & Bad \\
\hline Unlikable & & & & & & & & Likable \\
\hline Trustworthy & & & & & & & & Untrustworthy \\
\hline Honest & & & & & & & & Dishonest \\
\hline Sincere & & & & & & & & Insincere \\
\hline Not believable & & & & & & & Believable \\
\hline Convincing & & & & & & & & Unconvincing \\
\hline Certain & & & & & & & & Uncertain \\
\hline Not credible & & & & & & & & Credible \\
\hline Competent & & & & & & & & Incompetent \\
\hline
\end{tabular}

Based on the testimony that you read, carefully rate your impressions of Nancy Peters (the second witness for the plaintiff) as best you can on each of the following dimensions:

\begin{tabular}{|l|l|l|l|l|l|l|l|l|}
\hline Immoral & & & & & & & & Moral \\
\hline Respectable & & & & & & & & Not respectable \\
\hline Intelligent & & & & & & & & Unintelligent \\
\hline Good & & & & & & & & Bad \\
\hline Unlikable & & & & & & & & Likable \\
\hline Trustworthy & & & & & & & & Untrustworthy \\
\hline Honest & & & & & & & & Dishonest \\
\hline Sincere & & & & & & & & Insincere \\
\hline Not believable & & & & & & & & Believable \\
\hline Convincing & & & & & & & & Unconvincing \\
\hline Certain & & & & & & & & Uncertain \\
\hline Not credible & & & & & & & & Credible \\
\hline Competent & & & & & & & & Incompetent \\
\hline
\end{tabular}


Based on the testimony that you read, carefully rate your impressions of John Thomas (a shift supervisor in the maintenance garage at Sunshine Trucking Company) as best you can on each of the following dimensions:

\begin{tabular}{|l|l|l|l|l|l|l|l|l|}
\hline Immoral & & & & & & & & Moral \\
\hline Respectable & & & & & & & & Not respectable \\
\hline Intelligent & & & & & & & & Unintelligent \\
\hline Good & & & & & & & & Bad \\
\hline Unlikable & & & & & & & & Likable \\
\hline Trustworthy & & & & & & & & Untrustworthy \\
\hline Honest & & & & & & & & Dishonest \\
\hline Sincere & & & & & & & & Insincere \\
\hline Not believable & & & & & & & & Believable \\
\hline Convincing & & & & & & & & Unconvincing \\
\hline Certain & & & & & & & & Uncertain \\
\hline Not credible & & & & & & & & Credible \\
\hline Competent & & & & & & & & Incompetent \\
\hline
\end{tabular}

Based on the testimony that you read, carefully rate your impressions of Michael Richards (the director of fleet maintenance at Sunshine Trucking Company) as best you can on each of the following dimensions:

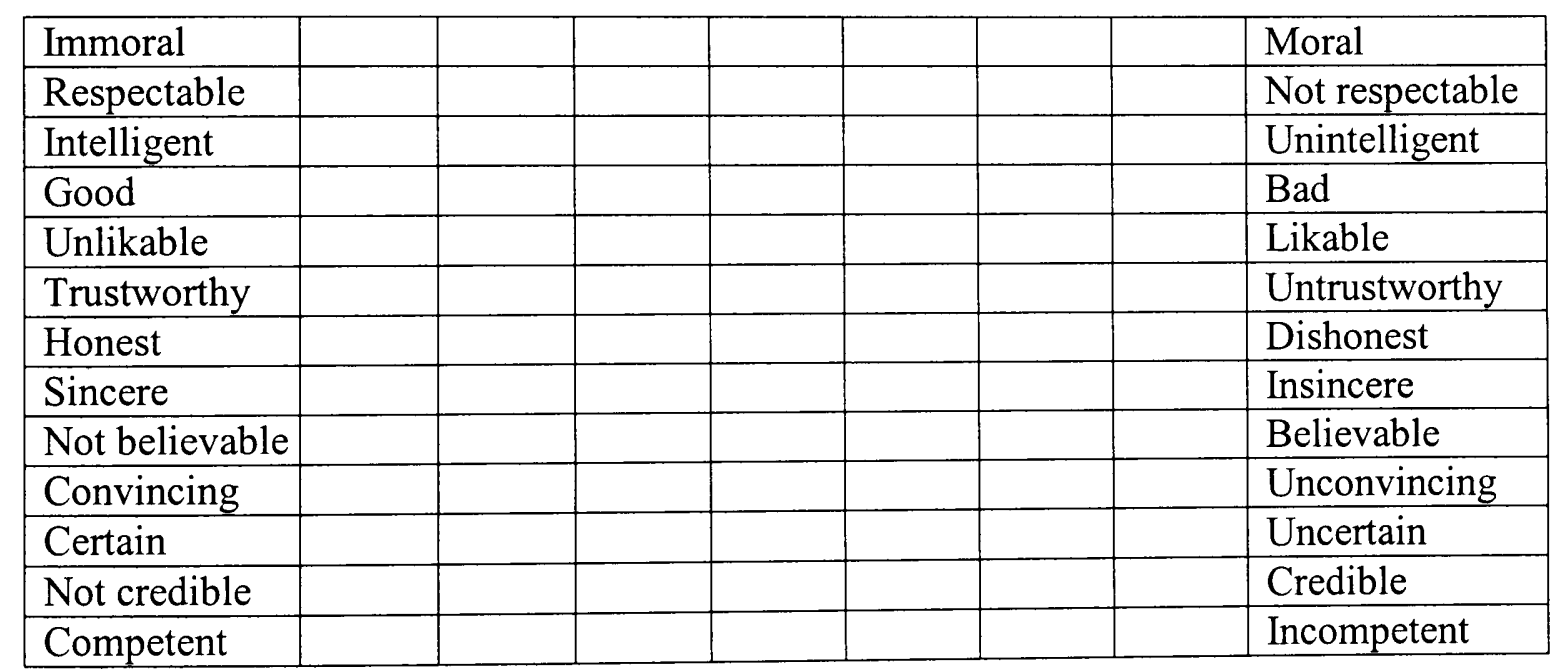


Instructions: In this section of the questionnaire, we are interested in your overall reactions to the trial. Please read each item carefully and circle the NUMBER that best reflects your opinion.

Ms. Hubbard (the plaintiff) worked in a hostile work environment at STC.

$\begin{array}{cccccc}1 & 3 & 4 & 5 & 6 & 7 \\ \begin{array}{c}\text { STRONGLY } \\ \text { DISAGREE }\end{array} & & & & & \text { STRONGLY } \\ \text { AGREE }\end{array}$

Mr. Richards's (the director of fleet maintenance) response to Ms. Hubbard's complaint was appropriate.
$\stackrel{1}{\text { STRONGLY }}$
$2 \quad 3$
34
5
7
STRONGLY
DISAGREE
AGREE

The pictures that hung at STC are not appropriate for the workplace.

$\begin{array}{ccccccc}1 & 2 & 3 & 4 & 5 & 6 & 7 \\ \text { STRONGLY } & & & & & \text { STRONGLY } \\ \text { DISAGREE } & & & & \text { AGREE }\end{array}$

No one should have to work in the environment described by Ms. Hubbard.

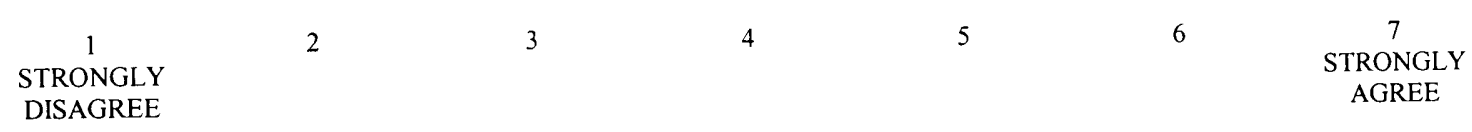

Ms. Hubbard's coworkers' behavior was extremely offensive.

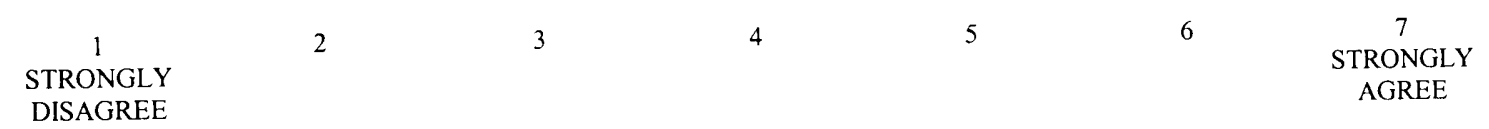

Sunshine Trucking Company did not take precautions to prevent a hostile work environment.

\begin{tabular}{|c|c|c|c|c|c|c|}
\hline $\begin{array}{c}1 \\
\text { STRONGLY } \\
\text { DISAGREE }\end{array}$ & 2 & 3 & 4 & 5 & 6 & $\begin{array}{c}7 \\
\text { STRONGLY } \\
\text { AGREE }\end{array}$ \\
\hline
\end{tabular}

Ms. Hubbard was the victim of pervasive sexual harassment.

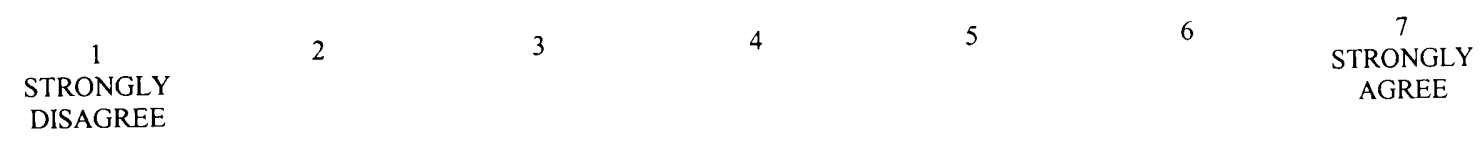

STC established its sexual harassment policy to protect the company from litigation.

$\begin{array}{cccccc}1 & 2 & 3 & 4 & 6 & 7 \\ \begin{array}{c}\text { STRONGLY } \\ \text { DISAGREE }\end{array} & & & & & \text { STRONGLY } \\ \text { AGREE }\end{array}$

STC took adequate preventative steps to ensure that employees did not work in a hostile work environment.

$\begin{array}{cccccc}1 & & 3 & 4 & 6 & 7 \\ \text { STRONGLY } & 2 & & & & \text { STRONGLY } \\ \text { DISAGREE } & & & & \text { AGREE }\end{array}$


Ms. Hubbard experienced extreme pain and suffering because of the sexual harassment she experienced at STC.

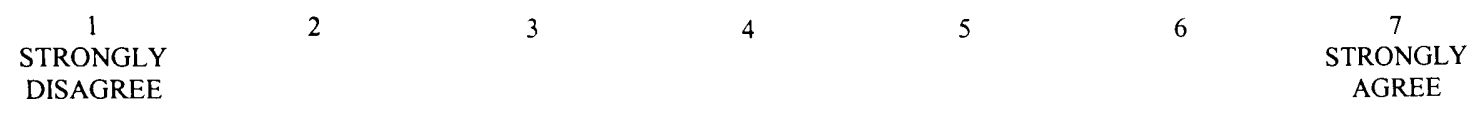

Ms. Hubbard suffered financially as a result of the sexual harassment she experienced at STC.

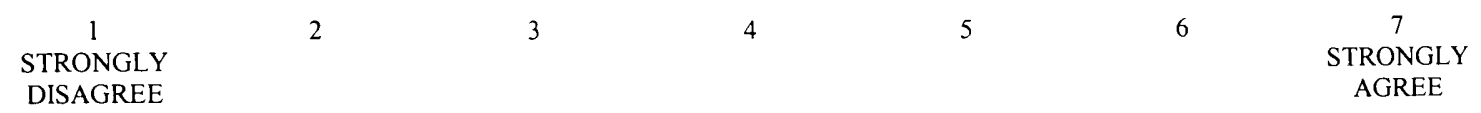

Sunshine Trucking Company should be punished for failing to prevent the behavior described in this case.

\begin{tabular}{|c|c|c|c|c|c|c|}
\hline $\begin{array}{c}1 \\
\text { STRONGLY } \\
\text { DISAGREE }\end{array}$ & 2 & 3 & 4 & 5 & 6 & $\begin{array}{c}7 \\
\text { STRONGLY } \\
\text { AGREE }\end{array}$ \\
\hline
\end{tabular}

Ms. Hubbard's work environment decreased the quality of her life.

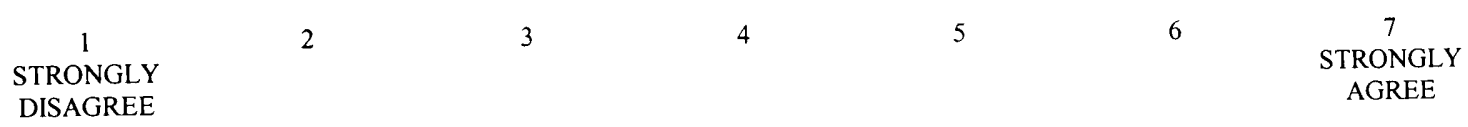

Sexual jokes, such as those as made by Jerry Frazier, are not acceptable in the workplace.
1
STRONGLY
3
4
5
6
STRONGLY
DISAGREE
AGREE

STC should not be punished for the actions of one or more of its employees.
STRONGLY
2
3
4
5
6
STRONGLY DISAGREE

Mr. Thomas's (the shift supervisor) response to Ms. Hubbard's claims was inadequate.
$\stackrel{1}{\text { STRONGLY }}$
2
3
4
5
6 STRONGLY AGREE DISAGREE

Ms. Hubbard's negative opinions of STC result from the sexual harassment she experienced on the job.

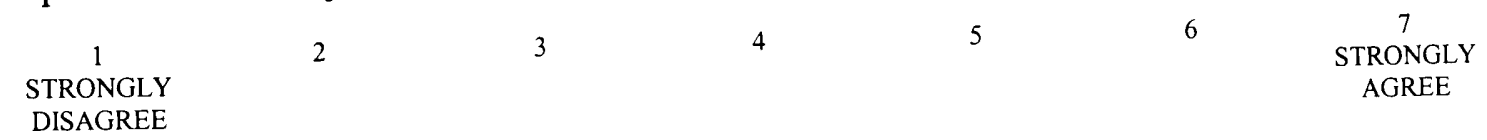

Sexual behaviors were pervasive throughout Sunshine Trucking Company.

$\begin{array}{cccccc}1 & 2 & 3 & 4 & 6 & 7 \\ \begin{array}{c}\text { STRONGLY } \\ \text { DISAGREE }\end{array} & & & & & \text { STRONGLY } \\ \text { AGREE }\end{array}$


The harassment Ms. Hubbard experienced was not pervasive enough to warrant compensation.
2
3
4
5
6
STRONGLY
DISAGREE

The sexual harassment experienced by Ms. Hubbard had a severe impact upon her life.

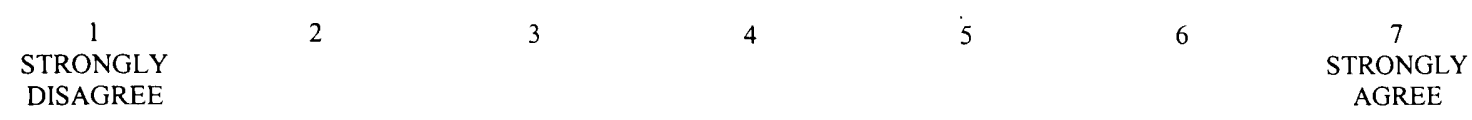

Sunshine Trucking Company's response to Ms. Hubbard's complaints was extremely inadequate

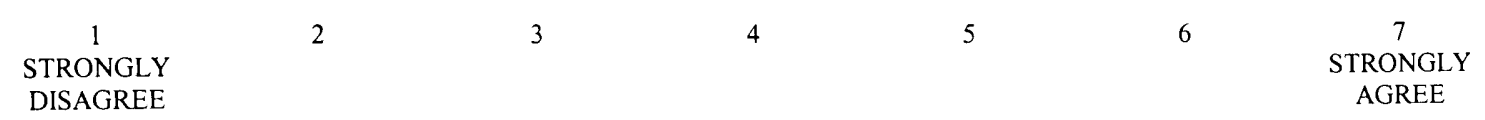

An example should be made of STC to discourage other companies from behaving in a similar manner.
1
STRONGLY
23
45
6
7
DISAGREE
STRONGLY

The male workers at STC were joking around with Ms. Hubbard, not sexually harassing her.

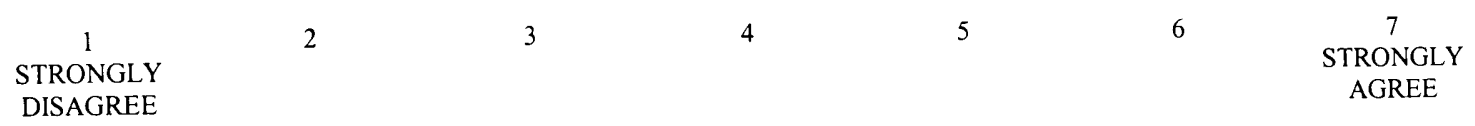

The questionable images displayed at STC are to be expected in a male-dominated work environment.

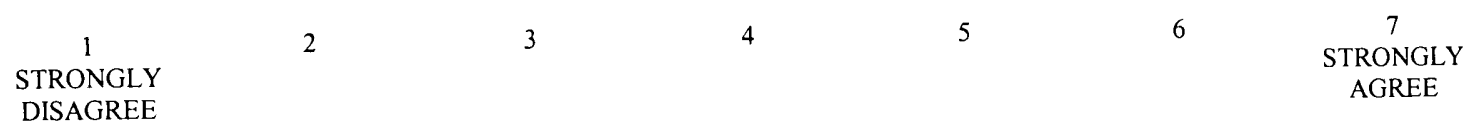

Ms. Hubbard suffered severe emotional distress as a result of the sexual harassment she experienced.

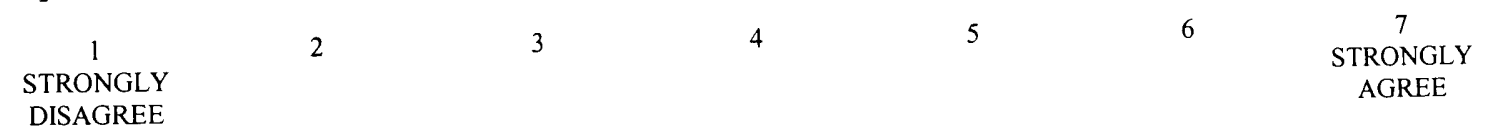

Ms. Hubbard was not the only woman at STC who experienced the events described during the trial.

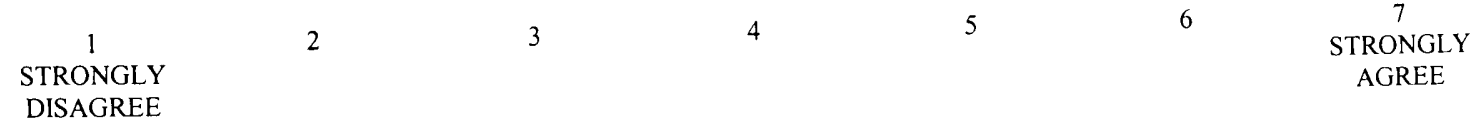


STC's sexual harassment policies were intended to prevent sexual harassment in the workplace.

$\begin{array}{llllrc}1 & 2 & 3 & 4 & 5 & 7 \\ \text { STRONGLY } & & & & \text { STRONGLY } \\ \text { DISAGREE } & & & & \text { AGREE }\end{array}$

\section{DEMOGRAPHIC CHARACTERISTICS}

We ask for the following information so we can describe the sample of respondents when we report the results of this research. Under NO circumstances will responses of individual jurors be reported. Naturally, you are not obligated to respond, but we hope you will do so.

1. What is your gender? MALE FEMALE

2. In what year were you born?

19

3. Are you a U. S. citizen?

YES

NO

4. What is your racial/ethnic background?

White, Non-Hispanic

Black, Non-Hispanic

Asian

Hispanic

Cuban

Other

5. What is the highest education level you have achieved?

Some High School High School Diploma

Some Graduate School

Some College College Degree (B.A./B.S.)

Graduate Degree (M.S./Ph.D.)

Other

6. If you went to college or are currently enrolled in college, what was/is your major?

7. Have you or anyone close to you been charged with sexual harassment? YES NO

8. Have you or anyone close to you been the victim of sexual harassment? YES NO

9. What is your current marital status?

SINGLE MARRIED DIVORCED WIDOWED PARTNERED

10. Have you ever served on a jury before?

YES

NO

If yes, was the trial:

CIVIL

CRIMINAL 
11. What is your current occupation? (Please check one)

\begin{tabular}{|c|c|c|}
\hline Craftsperson/laborer & Salesperson & Service Worker \\
\hline Professional/technical & Manager & Self-employed \\
\hline Clerical/secretarial & Teacher & Homemaker \\
\hline Not presently employed & Student & Retired \\
\hline
\end{tabular}

12. Which of the following best describes your total household income for 2000 before taxes?

\begin{tabular}{|c|c|c|}
\hline Less than 20,000 & 20,000 to 30,000 & 30,000 to 45,000 \\
\hline 45,000 to 60,000 & 60,000 to 75,000 & \\
\hline
\end{tabular}

Thank you.

Please return your packet to the experimenter. 